\title{
DEVELOPMENT LEVEL OF HOSTING AREAS AND THE IMPACT OF REFUGEES ON NATIVES' LABOR MARKET OUTCOMES
}

\author{
Doğu Tan Arac1 \\ Murat Demirci \\ Murat Güray Kırdar
}

Working Paper No: 2102

April 2021

This Working Paper is issued under the supervision of the ERF Directorate. Any opinions expressed here are those of the author(s) and not those of the Koç University-TÜSİAD Economic Research Forum. It is circulated for discussion and comment purposes and has not been subject to review by referees.

KOÇ UNIVERSITY-TÜSİAD ECONOMIC RESEARCH FORUM

Rumelifeneri Yolu 34450 Sarıer/Istanbul 


\title{
Development Level of Hosting Areas and the Impact of Refugees on Natives' Labor Market Outcomes *
}

\author{
Doğu Tan Araci ${ }^{1}$, Murat Demirci ${ }^{\gtrless}$, and Murat Güray Kırdar ${ }^{\#}$
}

March 29, 2021

\footnotetext{
*. We would like to thank Abdurrahman Aydemir and Insan Tunali for their valuable comments and suggestions. The usual disclaimer holds.

${ }^{1}$ Prosus, Amsterdam, 1082MS, The Netherlands. e-mail: dogu.araci@prosus.com

${ }^{r}$ Department of Economics, Koç University, Sarıyer, Istanbul 34450 Turkey. e-mail: mudemirci@ku.edu.tr

\# Department of Economics, Boğaziçi University, Bebek, Istanbul 34342 Turkey. e-mail: murat.kirdar@boun.edu.tr
} 


\begin{abstract}
We examine how the impact of refugees on natives' labor market outcomes varies by the development level of hosting areas, which has important implications for the optimal allocation of refugees across regions and countries. For this purpose, in the context of the largest refugee group in the world in a single country, Syrian refugees in Turkey, we exploit the significant variation in the development level across regions of Turkey, several of which host a substantial number of refugees. We find that the impact of refugees on natives' labor market outcomes becomes significantly less adverse as regional development level rises. For instance, the negative effects of the refugee shock on employment and labor force participation of women observed at the mean level of development vanish at high levels of development. Moreover, while the impact of the refugees on employment of men is negative for the least developed regions, it is positive for highly developed regions. Our findings imply that developed regions and countries are in a better position in terms of protecting their local population from the adverse effects of refugees in the labor market.
\end{abstract}

Keywords: refugees, optimal refugee allocation, labor market impact, development level, employment and wages of men and women

JEL Codes: J61, O15, F22, R23, R58 


\section{Introduction}

At the end of 2019, there were 79.5 million forcibly displaced individuals in the world-which means that 1 in every 103 people around the world was forcibly displaced (UNHCR, 2021a). Of these 79.5 million forcibly displaced individuals, 26 million were refugees. Most of these people (73\%) settle in the countries neighboring their country of origin (UNHCR, 2021a), which bear the costs of integration of refugees and happen to be mostly less developed countries. Although these neighboring countries generally get financial help from rich countries and international donors for the extra housing, health, and education costs of refugees, the local population of these countries who lose their jobs or who see their wages drop mostly go uncompensated. In fact, several studies point out adverse short-term effects of refugees on labor market outcomes of natives in the neighboring countries (at least for certain subpopulations). ${ }^{1}$ On the other hand, studies on the impact of refugees on natives' labor market outcomes in developed countries generally find less adverse effects. ${ }^{2}$ In fact, reviewing a wide literature in economics on the impact of forced displacement on host communities, Verme and Schuettler (2021) conclude that adverse effects on employment and wages are more likely to occur in middle-income than high-income countries. This contrast suggests that the impact of refugees on natives' labor market outcomes could differ by the level of development of host countries. However, the observed differences in the impact of refugees across countries might also stem from the existence of different institutions in developed and less developed countries. To understand the relationship between the refugee impact and the development level, we examine how the impact of refugees on natives' labor market outcomes

\footnotetext{
${ }^{1}$ Examining the effects of internal displacement in Colombia on labor market outcomes of residents of hosting regions, Bozzoli et al. (2013), Calderon-Mejia and Ibanez (2016), Morales (2017) find a negative wage effect of migrants. However, they do not find much employment displacement as the informal sector absorbs the forced migrants. Similarly, Bryant and Rukumnuaykit (2013) find a negative wage impact but no employment effect of refugees from Myanmar on natives in Thailand. In the context of refugee inflows from Burundi and Rwanda to Tanzania, Maystadt and Verwimp (2014) find a negative effect on Tanzanian agricultural workers but a positive effect on agricultural producers. Aydemir and Kurdar (2017) find that the arrival of ethnic Turks from Bulgaria into Turkey in 1989 increases the unemployment rate of native men. Aksu et al. (2018) find that the arrival of Syrian refugees lowers female employment and labor force participation and decreases men's employment in the informal sector while increasing men's employment and wages in the formal sector. Malaeb and Wahba (2018), in the context of Syrian refugees in Jordan, find that the arrival of refugees pushes earlier migrants into the informal sector and lowers their working hours and wages. Becker and Ferrera (2019) provides a review of this literature.

${ }^{2}$ Most studies using natural experiments find small short-term effects of refugee shocks on natives' labor market outcomes in developed countries (see, for instance, Card, 1990; Hunt, 1992; Friedberg, 2001; Cohen-Goldner and Paserman, 2011; Foged and Peri, 2016; Peri and Yasenov, 2019), although others find stronger negative short-term effects (see, for instance, Glitz, 2012; Borjas and Monras, 2017; Borjas, 2017).
} 
changes with the development level of the hosting regions within a particular country — which share common institutions. In particular, we examine the labor market impact of Syrian refugees across different regions of Turkey until 2015.

The observed correlation between the refugee impact and development level of countries could result from differences across destination countries in legal and institutional frameworks, particularly with regard to the rights and access of refugees to the labor market, education and health services, training and humanitarian-aid programs. In addition, more developed countries might be in a better position to manage and smooth the transition of refugees due to their better institutional capacity and financial resources. In this study, since we are comparing regions with significantly different levels of development within the same country-one where the central government is strong and where the legal and labor market frameworks are common-we can overcome the above confounding factors and tease out the role of the level of development in determining the refugee impact. ${ }^{3}$

Another potential confounding factor in the cross-country correlation between the refugee impact and development level is the sorting of refugees across potential destinations based on their characteristics. For instance, more educated refugees might be more able to settle in more developed countries. ${ }^{4}$ In our context, however, since the settlement patterns of refugees are mostly based on distance to their original homes as they flee the war, the refugees were more or less randomly allocated at least in the short term. In fact, we formally examine potential sorting of refugees across regions by educational attainment using the refugee sample of the 2018 Turkish Demographic and Health Survey (TDHS) and find no evidence for such sorting. ${ }^{5}$

Most Syrian refugees in Turkey have low levels of education and almost all employed individuals among them work in the informal sector (with no social security coverage). The regions of Turkey

\footnotetext{
${ }^{3}$ Aydemir and Yazici (2019) use a similar approach in their investigation of the link between regional development and intergenerational education mobility.

${ }^{4}$ In fact, the selection of Syrian refugees into developed countries in terms of education seems to be more positive. Germany's Office for Migration and Refugee (BAMF) finds that around half of surveyed Syrians in Germany reported having either a university degree or a high-school diploma (MiGazin, 2015), whereas only a quarter of the Syrian refugees in Turkey have the same educational attainment (TDEMA, 2016).

${ }^{5}$ Among the 1,826 refugee households in the refugee sample of the 2018 TDHS, the mean years of education of household heads is 6.58 in western Turkey (383 observations), 6.94 in southern Turkey (690 observations), 6.71 in central Turkey (118 observations), and 6.51 in eastern Turkey ( 635 observations). When we run a regression of years of education on region dummies, the joint statistical significance of region dummies is rejected ( $p$-value $=0.35$ ).
} 
that lie close to the border with Syria received significant levels of refugees, but these regions also differ substantially in terms of development level. We primarily rely on this variation to identify how the labor market impact of refugees varies with the level of development. Our approach is similar to that of Angrist and Kugler (2003), who examine how the impact of immigrants on natives' employment varies by labor market flexibility. ${ }^{6}$ While Angrist and Kugler use the variation in certain measures of labor market flexibility across European countries, we exploit the variation in development level across regions of a single country-while holding other factors such as labor market institutions and legal framework constant. ${ }^{7}$

The context of our study is important because Syria is the top source country of refugees in the world (6.6 million) and Turkey is the top host country (3.6 million refugees). While Syrian refugees constitute $4.4 \%$ of the population in Turkey (UNHCR, 2021b), this percentage is much lower in Europe with significant variation across EU countries. ${ }^{8}$ In fact, the coordination of the settlement and integration of refugees, many of which enter Europe via Turkey, has become a major policy challenge for the EU. The EU policy makers are discussing the optimal allocation of these refugees across the member countries, as well as compensation payments for countries that receive a disproportionately higher number of refugees. Understanding the relationship between the impact of refugees and the development level of hosting regions in the context of Turkey where the economic structure of developed regions display similar traits of an average EU country, would provide some guidance on the debate about the optimal allocation of refugees across EU countries.

\footnotetext{
${ }^{6}$ Their analysis focuses on three features of labor market institutions: 1) labor market standards measuring employment protection, restrictions on hours worked and flexibility of hiring and firing, 2) replacement rates indicating the strength of unemployment benefits, 3) entry costs measuring barriers to entrepreneurship. They find that the impact of immigrants is more adverse in countries with less flexible labor markets, higher replacement rates, and higher entry costs.

${ }^{7}$ Our study differs from that of Angrist and Kugler because the analyzed regions in our study share a common legal framework imposing the same laws of employment and entrepreneurship and the same regulations for unemployment benefits. However, the development level of regions differs in our analysis because of differences in human capital of their residents, the industrial structure of their economies, the access of firms to financial services, their distance to major transportation routes, and innovative capacity of their entrepreneurs. To capture all these dimensions of development, we use an index of development, which is constructed by the Turkish Ministry of Development based on various measures of these dimensions. See Appendix Table A1 for the full list of measures that the development index is calculated from.

${ }^{8}$ While the percentage was $0.69 \%$ in Germany in 2019, it was much lower in the other large European countries. Similarly, while it was 1.1\% in Sweden in 2019, it was much lower in other Nordic countries (Statista, 2021).
} 
Turkish regions display substantial variation in terms of development level. Of the five NUTS-2 regions with the highest refugee density, in 2011, the Sanliurfa Region had a GDP per capita at ppp that was on par with those of Namibia, Indonesia, and Jordan; whereas, the GDP per capita at ppp in the Adana Region was on par with that of Bulgaria. At the same time, the average purchasing power in the Istanbul Region in 2011 was similar to those of Slovenia and the Czech Republic. In addition, across the five regions on the Syrian border with the highest refugee intensity, as we move from west to east, the level of development falls gradually. In particular, educational attainment and average age fall, the employment rate of women and the share of formal workers among employed men decrease, the shares of agriculture and construction rise and the share of manufacturing drops. In other words, as we move from west to east, regions begin to display canonical traits of developing countries.

The level of development of the hosting regions matters for the impact of refugees on natives' labor market outcomes for a number of reasons. First, the arrival of refugees changes the relative abundance of different factors of production. Refugees, who are mostly unskilled, young, and less educated are closer substitutes to natives in the labor market of less developed regions - who are similar in these traits. ${ }^{9}$ On the other hand, in more developed areas, refugees are likely to complement natives, many of whom work in manufacturing and service sectors as more skilled workers. Moreover, in these regions, the arrival of refugees could upgrade natives to more demanding jobs. ${ }^{10}$ Second, in less developed areas, there are more jobs in agriculture and construction and more informal jobs in manufacturing and services, which do not require many qualifications. ${ }^{11}$ Hence, it is easier for refugees to secure jobs in these areas, which would crowd out employment of more natives and put larger downward pressure on native earnings in these areas. Third, a lower level of development might be associated with less competitive businesses, a

\footnotetext{
${ }^{9}$ Calderon-Meija and Ibanez (2016) and Aksu et al. (2018) find a high degree of substitutability between migrants and low-skilled natives in the informal sector in the context of Colombia and Syrian refugees in Turkey, respectively.

${ }^{10}$ Using a large dataset of firms in Turkey, Akgündüz and Torun (2020) find that the arrival of Syrians pushes native workers into more complex jobs by increasing the intensity of more abstract and routine tasks at the expense of manual tasks. Using data on 15 European countries, D'Amuri and Peri (2014) document that immigrants push natives into more complex jobs. Similarly, Peri and Sparber (2009) report that the arrival of migrants pushes natives in the US from jobs that require manual skills to jobs that require English-language skills.

${ }^{11}$ In fact, in the context of Syrian refugees in Turkey, Aksu et al. (2018) find substantial displacement of native men in construction and both native men and women in agriculture by refugees.
} 
lower ability to create new jobs/positions (i.e., less ability to attract new investment etc.) and high labor market frictions (such as not being able to access job posts).

In terms of methodology, we use the synthetic control method (SCM) of Abadie and Gardazabal (2003) to construct control groups for each region. We construct synthetic controls for each of the 26 regions of the country and then run regressions across the 26 regions and their synthetic controls over time, with pair fixed effects, to estimate how the impact of refugees varies by the development level of regions. The SCM very much fits our purpose in this study because it allows examining the migrant impact on each region separately by constructing the best possible control group for that region given the available pool of donors. In addition, as illustrated by Aksu et al. (2018), strong time trends exist in the major labor market outcomes in the pre-shock period in Turkey. The SCM provides a data-driven technique to capture the closest trend for each region. The SCM does not take into account the potential endogeneity of the distribution of migrants across Turkish regions. However, as illustrated by Aksu et al. (2018), distance from the Syrian border was the key determinant of the settlement patterns of Syrian migrants until 2015.

We find that the impact of refugees on total employment and formal employment of both native men and women becomes less adverse as regional development rises. While no effect on men's employment exists at the mean level of development, a positive effect emerges at high levels of development and a negative one at low levels of development. The adverse effects of the refugee shock on women's employment and labor force participation are observed only in regions with low levels of development. Similarly, the refugee shock raises the unemployment rates of both men and women only at low levels of development. In addition, the transition of native workers from informal to formal employment as a result of the arrival of refugees is stronger in more developed regions.

Our findings provide important policy implications on the optimal distribution of refugees across regions within a single country. First, mobility restrictions on refugees, which would prevent their migration to the more developed regions of the country, would be detrimental for natives' labor market outcomes. Second, the initial locations of refugee camps should not be chosen in less developed regions so that the effects of refugees can be better absorbed. In addition, our findings also provide insights into the optimal distribution of refugees across countries, at least among those that share common political and economic institutions such as the EU. The finding that the impact 
of refugees on natives' labor market outcomes becomes less adverse as the development level of hosting regions rises implies that the labor market cost of hosting refugees is lower for natives of more developed countries.

The outline of this article is as follows. In Section 2, we provide background information on Syrian refugees in Turkey and on the labor market in Turkey. Data and descriptive statistics are given in Section 3, and the identification strategy and estimation are provided in Section 4. Section 5 presents the results and robustness checks. Section 6 concludes.

\section{Background Information}

In this section, we provide brief information on the Syrian refugees in Turkey and the labor market conditions in Turkey before the arrival of refugees.

\subsection{Syrian Refugees in Turkey}

After the Arab Spring uprisings that started in 2010, Syria was dragged into a civil war. By February 2018, this civil war had displaced 13.1 million Syrians, half of the country's population, and 5.6 million of these displaced individuals took refuge in other countries (UNHCR, 2018). Turkey was the largest recipient of these refugees in terms of numbers, although Lebanon and Jordan received more as a fraction of their population. Syrians in Turkey do not have refugee status officially but are under "temporary protection." 12

Turkey first took refugees from Syria in April 2011 but the numbers, around 8,000, were very small until the end of 2011. As the war worsened in Syria, the number of refugees entering Turkey accelerated. The number of Syrians increased to 170,912 by the end of 2012, to 506,129 by the end of 2013, and reached 1,622,839 by the end of 2014 and 2,503,549 by the end of 2015. As Ferris and Kirisci (2016) report, these refugees left Syria due to security reasons and chose Turkey as the destination due to the ease of transportation. In fact, a large fraction of the Syrians in Turkey originates from the northern provinces of Syria bordering Turkey such as Aleppo and Idlib (Aksu et al, 2018). Many refugees settled in urban areas; only 10\% of Syrians in Turkey lived in refugee

${ }^{12}$ They officially gained this status in October 2011. 
camps at the end of 2015. (Turkish Directorate of General Migration Management, TDGMM, 2016).

Syrian refugees are on average younger and less educated than natives. Based on the numbers of Syrians by age group provided by the TDGMM, Eryurt (2017) calculates that the median age of Syrians as 21, compared to 31 for natives. While the median years of schooling is 4.8 for Turkish women and 7.1 for Turkish men, it is 4.5 for Syrian women and 5.1 for Syrian men (Hacettepe University Institute of Population Studies, 2019a, 2019b). In particular, the fraction of individuals with no school degree is higher among refugees. The fraction of individuals with no school degree is $25.1 \%$ among Turkish women and $13.5 \%$ among Turkish men, whereas it is $40 \%$ among Syrian women and 35\% among Syrian men (Hacettepe University Institute of Population Studies, 2019a, 2019b).

Almost all employed Syrian refugees in Turkey work in the informal sector. In fact, before the enactment of Law 8375 in January 2016, which allowed Syrian refugees under temporary protection to have work permits under certain conditions and restrictions, only a total of 7,351 work permits were issued for Syrians (Ministry of Labor and Social Security). The anecdotal evidence points to construction, agriculture, and textiles and clothing manufacturing as the major sectors where many refugees worked informally. In fact, Aksu et al. (2018) find substantial displacement of natives working in the informal construction, agriculture, and textiles and clothing manufacturing sectors by the refugees. They also find a positive impact of refugees on formal employment of natives in the manufacturing and service sectors. Unfortunately, no official statistics or representative surveys of Syrians for the pre-2016 period exists. Examining a number of other surveys on the refugees, Aksu et al. (2018) state that these surveys suggest that the employment rate is $30-40 \%$ and the labor force participation is about $50 \%$, although a large gender gap exists in these percentages.

\subsection{Labor Market Conditions in Turkey}

The statistics we provide in this subsection are for 18- to 64-year-old individuals (as in the sample used in our empirical analysis) and are based on the 2011 Turkish Household Labor Force Survey (the last survey before the arrival of Syrians). While the labor force participation rate of men in Turkey is similar to that of OECD countries (except for older workers due to the early retirement possibilities that were available for them), the female labor force participation rates are much lower 
for all age groups in Turkey (Dayığlu and Kırdar, 2010). In 2011, before the arrival of Syrian refugees, the participation rate of women was only 33\%. The unemployment rate in 2011 was 9.2\% for men and $11.5 \%$ for women. A significant fraction of workers in Turkey are not wage earners. Self-employment among employed men (21.6\% in 2011) and unpaid family work among employed women (34.2\% in 2011) are common. In addition, agriculture still provides a significant part of employment, $40.5 \%$ of all employed women and $16.8 \%$ of all employed men were in agriculture in 2011.

Many workers in Turkey are employed informally-without social security coverage. In fact, a third of all employed men and 56\% of all employed women work informally. The fraction among women is high primarily because of the higher incidence of their working in agriculture. Although informality in Turkey is not restricted to certain sectors, it is more common in agriculture and construction. In 2011, the incidence of informality was $82.6 \%$ in agriculture compared to lower than $25 \%$ in each of the manufacturing and services sectors. Informality is not limited to lesseducated people either, although it is more likely for them. In 2011, while $85.6 \%$ of those with no school degrees were informally employed, $49.2 \%$ of primary school or middle school graduates, $22.9 \%$ of high school graduates, and $7.4 \%$ of college graduates were. In terms of type of employment, informality is observed less frequently among wage workers than among the selfemployed because the latter group is more likely to be in agriculture. In 2011, 23.4\% of wage workers were informally employed compared to $63.6 \%$ of the self-employed.

An important feature of the Turkish labor market during the era preceding the arrival of refugees was the strong time trends in many key outcomes. First, formal employment grew at the expense of informal employment. According to the Turkish Household Labor Force Surveys, the percentage of 18- to 64-year-old men employed in the formal sector increased from $41.2 \%$ to $49.2 \%$ between 2004 and 2011, while the percentage of those employed in the informal sector decreased from $29.7 \%$ to $24.2 \%$. Second, a sharp increase in the fraction of wage earners among all employed individuals is observed at the expense of self-employed and unpaid family workers. The fraction of wage earners increased from $59.4 \%$ to $67.3 \%$ for men and from $46.6 \%$ to $53.0 \%$ for women between 2004 and 2011. Third, for women, labor force participation and employment 
rose significantly in this period. The fraction of women in the labor force increased from $26.3 \%$ to $33.0 \%$ and the fraction of women employed rose from $23.3 \%$ to $29.2 \% .^{13}$

\section{Data}

We use the 2004-2015 Turkish Household Labor Force Surveys (THLFS), conducted by the Turkish Statistical Association (TurkStat). These surveys have repeated cross-sectional structure and are representative at the 26 NUTS-2 level. Therefore, our unit of analysis in the synthetic control methods is NUTS-2 regions. Since the target population of these surveys are permanent residents of Turkey, Syrian refugees — who have temporary migrant status — are not included. The sample is restricted to 18 - to 64-year-old individuals. We start with the 2004 survey because a major revision was conducted in the survey structure in this year. We focus on the impact of refugees until 2015 because the minimum wage was increased by about 30\% in 2016, which generated an important shock to the Turkish economy. Bakis and Polat (2021) report that 45.1\% of all private sector workers and $37.1 \%$ of formally employed private sector workers earn below 1.05 times the minimum wage.

The THLFS have detailed information on labor market outcomes, as well as information on demographics. The labor market outcomes we examine include employment, unemployment, labor force participation, and hourly wages. We generate the data on hourly wages using the information in the survey on monthly wages and the hours of work in the reference week (which we multiply by 4.3 to generate the monthly hours of work). We also use information on the type of employment (wage employment, self-employment, unpaid family work, employer) and the aggregate sector of employment (agriculture, manufacturing, construction, services). In addition, we have information on the formal vs. informal status of employment-which is generated according to the question in the survey on the social security coverage status of an individuals' employment. Basic demographics such as gender, age and educational attainment are also included in the survey.

The data for the number of Syrians across these regions come from different sources. The sources of the data are the Turkish Disaster and Emergency Management Authority for $2013,{ }^{14}$ Erdogan

\footnotetext{
13 Tunalı et al. (2019) discuss the underlying reasons for the increasing participation rate for women in Turkey.

${ }^{14}$ Exact numbers of Syrians for provinces with refugee camps are provided and it is reported that 80,000 refugees resided in provinces with no camps. We allocated these 80,000 refugees across provinces with no camps based on the
} 
(2014) for 2014 (which is based on data disseminated by the Turkish Ministry of Interior), and the Turkish Directorate General of Migration Management for 2015. These numbers are provided for the end of each year; however, as shown in Figure 1, the number of refugees changed significantly from the beginning to the end of these years due to the continuous flow of refugees. Hence, we adjust these numbers across provinces so that they represent the year average rather than the year end - using data from the UNHCR on the number of Syrian refugees in Turkey by month. ${ }^{15}$ We aggregate the provincial numbers to NUTS-2 level, which is the unit of analysis with the THLFS data.

We use the Socio-economic Development Index, constructed periodically by the Turkish Ministry of Development as a measure of development of each region in Turkey. The index measures development level as a function of various indicators related to demographics, employment, education, health, competitiveness and innovation, financial development, transportation and telecommunication, and life quality. ${ }^{16}$ The index is normalized such that its mean is zero and its standard deviation is one. We use values from the 2011 index, a year prior to the start of refugee flows, to eliminate concerns about potential impact of refugees on the development level of regions.

\subsection{Descriptive Statistics}

In Table 1, we provide information on key characteristics of NUTS-2 regions in Turkey. Two of the five focus regions, the Adana Region (NUTS-2 region 12) and the Hatay Region (NUTS-2 region 13) are geographically in the Mediterranean region, whereas the other three, the Gaziantep Region (NUTS-2 region 24), the Sanliurfa Region (NUTS-2 region 25), and the Mardin Region (NUTS-2 region 26) are in southeastern Anatolia. The population of each region is between two and four million. The development index takes the value of 0.521 for the Adana Region, -0.055 for the Gaziantep Region, -0.273 for the Hatay Region, -1.147 for the Sanliurfa Region, and -1.328

\footnotetext{
shares of Syrians in these provinces in 2014.

${ }^{15}$ First, for each year, we calculate the average value of the monthly numbers of Syrian migrants (call this $x[t]$, where $\mathrm{t}$ denotes the year) using the monthly numbers from the UNHCR. Then we calculate the total number of Syrian migrants in Turkey using the cross-sectional data for each year (call this $y[t]$ ). We adjust the regional numbers in the cross-sectional data by multiplying it by $x[t] / y[t]$ to match the sum of regional numbers in each year with the average monthly value for that year.

${ }^{16}$ The index in 2011 is constructed with the principal component analysis based on 61 variables. See Turkish Ministry of Development (2013) for detailed information about the construction of the index.
} 
for the Mardin Region. These five regions have markedly higher ratios of migrants to natives. In 2015, it was 0.134 for the Gaziantep Region, 0.114 for the Hatay Region, 0.086 for the Sanliurfa Region, 0.050 for the Adana Region, and 0.044 for the Mardin Region. On the other hand, it was 0.018 for the Istanbul Region, which ranks sixth in this measure.

Descriptive statistics for the five NUTS-2 regions with the highest ratio of migrants to natives, as well as for the whole country, are given by gender for demographic outcomes in Table 2 and for labor market outcomes in Table 3. In both tables, the five focus regions are ordered across the columns from the left to the right in terms of decreasing development index. Table 2 shows that as development level decreases, educational attainment falls for both men and women. For instance, the fraction of individuals with no degree increases from $23.8 \%$ in the Adana Region to $67.4 \%$ in the Sanliurfa Region for women and from $8.3 \%$ in the Adana Region to $23.9 \%$ in the Sanliurfa Region for men. This group is important because Syrian refugees would be the closest substitute for this group with the lowest educational attainment. Similarly, as the development level drops, natives on average become younger. ${ }^{17}$ Essentially, the populations of the Sanliurfa and Mardin regions are much less educated and younger than that of the Adana Region. While the Hatay and Gaziantep regions lie in between in terms of these outcomes, they are closer to the Adana Region than to the two less developed regions.

As can be seen from Table 3, employment outcomes display large variations across the five regions. Of the 18- to 64-year-old male population, while 67-69\% are employed in the Adana, Hatay, and Gaziantep regions, 59-61\% are employed in the Sanliurfa and Mardin regions. This difference is more acute among women. While about $22.5 \%$ are employed in Adana and Hatay regions in the Mediterranean, $12.5 \%$ are employed in Gaziantep (which is economically developed but socially conservative), and $8.2 \%$ and $7.4 \%$ are employed in the Sanliurfa and Mardin regions, respectively (both of which are economically less developed and socially conservative). Table 3 also shows that the labor force participation rate is lower in the less developed regions both for men and women.

Among men, formal employment drops as development level decreases. While $53.2 \%$ of employed men work formally in the Adana Region, $31.5 \%$ do in the Sanliurfa Region. Essentially, while it

\footnotetext{
${ }^{17}$ While $19.8 \%$ of women in the Adana Region are 18- to 24-year-old, $29.3 \%$ are in the Mardin Region; similarly, $18.5 \%$ of men in the Adana Region belong to this age group compared to $25.2 \%$ in the Mardin Region.
} 
is the employment rate that drops for women as development level decreases, it is the share of formal workers for men that falls. In addition, the fraction of non-wage workers among women is higher in the less developed regions because of the importance of agriculture in generating jobs for women in these areas. Finally, the fraction of wage workers among women and the fraction of formally employed wage workers among men are lower in less developed regions. ${ }^{18}$

The outcomes by the sector of employment indicate that as development level falls, the sectoral distribution of employment becomes more typical of developing countries. For instance, while the fraction of women employed in agriculture is $39.6 \%$ in the Adana Region, it is $63.2 \%$ in the Sanliurfa Region. In a parallel manner, the fraction of women employed in manufacturing falls from $14.6 \%$ in the Gaziantep Region to $2.2 \%$ in the Sanliurfa Region and to $3.3 \%$ in the Mardin Region. ${ }^{19}$ Among men, differences in the sector of employment are less acute but still important. While $28.0 \%$ of men work in the manufacturing sector in the Gaziantep Region, ${ }^{20}$ only $7.9 \%$ in the neighboring Sanliurfa Region and 10.2\% in the Mardin Region do. In essence, the sectoral employment of men in the Adana and Hatay regions are similar to the country average, while the Gaziantep Region has a higher fraction in manufacturing but a lower fraction in services. On the other hand, the less developed Sanliurfa and Mardin regions have higher fractions in agriculture and construction but much lower fractions in manufacturing.

The observed patterns in the values of the development index, shown in Table 1, which increase from west to east across regions of interest, is consistent with the pattern that is inferred based on employment- and demographic-related indicators of development in the THLFS (given in Tables 2 and 3). As described above, the Turkish Ministry of Development employs information on competitiveness and innovation capacities of each region in addition to demographic and employment indicators. Apparently, the ordering of regions with respect to broader dimensions of development is similar to the ordering with respect to demographic and employment indicators.

\footnotetext{
18 Since the share of public workers is high in the less developed regions - where a larger fraction of the formally employed individuals, especially among women, are government-appointed education and health personnel—mean wages are actually higher for women in these regions and mean wages in the formal sector are higher for both men and women.

${ }^{19}$ These patterns take place despite the fact that the Adana and Hatay regions sit on some of the most productive agricultural land and have the best climate for agriculture in the country.

${ }^{20}$ In fact, the city of Gaziantep is one of the most important manufacturing centers in the country.
} 


\section{Empirical Methodology}

In the first stage of our empirical strategy, we quantify the impact of Syrian refugees on labor market outcomes of native workers in host regions. We achieve this by comparing the actual outcomes realized after the influx of refugees to a region with the counterfactual outcomes that would have been observed in the absence of refugees in that region. We employ the Synthetic Control Method (SCM), initially developed by Abadie and Gardeazabal (2003), to infer the counterfactual outcomes. In the second stage of our empirical strategy, pooling the realized and counterfactual outcomes for all regions, we employ a regression analysis to explore the relationship between the impact of refugees and the development level of host regions.

\subsection{The Synthetic Control Method}

First, we briefly outline the SCM. Suppose that $\mathrm{J}+1$ regions exist that are indexed by $j=0,1,2, . ., \mathrm{J}$. Let the index 0 denote the region where an event has occurred (i.e., the influx of Syrian refugees in our application). None of the remaining regions has experienced the event. The donor pool consists of all these other regions indexed from 1 to J. Let $X_{0}$ be a column vector of dimension K. Each element of $X_{0}$ shows the value of a variable for the region 0 . These variables are predictors of the outcome of interest in the pre-event period. Let $X$ be a $\mathrm{K}$ by $\mathrm{J}$ matrix whose $j^{\text {th }}$ column shows values of the same predictors in region $j$ of the donor pool.

The SCM allows us to estimate the vector of weights, $W=\left(w_{1}, w_{2}, \ldots, w_{J}\right)$, of which $j^{\text {th }}$ element is equal to the weight of the region $j$ of the donor pool. The method chooses optimal weights by minimizing the squared deviation between the values of predictors for the region that has experienced the event and the weighted sum of values of predictors for regions in the donor pool. In other words, the SCM finds optimal weights as the solution of the following problem.

(1) $\quad W^{*}=\operatorname{argmin}\left(X_{0}-X W\right)^{\prime} V\left(X_{0}-X W\right) \quad$ subject to $\sum_{j=1}^{J} w_{j}=1$ and $w_{j} \geq 0$ for each $j$.

Let $Y_{j t}$ denote the outcome variable in region $j$ at time $t$, and let $\widehat{Y}_{0 t}$ denote the value of the outcome that would have been observed in the absence of Syrian refugees in region 0 at time $t$. After finding the optimal weights $\left(W^{*}\right)$, the counterfactual outcome, $\hat{Y}_{0 t}$, is calculated as the weighted sum of the realized outcome in regions of the donor pool. In other words, the outcome in the synthetic control unit for region 0 is calculated as 


$$
\widehat{Y}_{0 t}=\sum_{j=1}^{J} w_{j}^{*} Y_{j t}
$$

The impact of the event in region 0 at time $t$, which is denoted by $\Delta_{0 t}$, is calculated as the difference between the actual and counterfactual outcomes:

$$
\Delta_{0 t}=Y_{0 t}-\hat{Y}_{0 t}
$$

Inference about statistical significance of the estimated impact can be conducted based on placebo permutations as suggested by Abadie et al. (2010). According to that method, the impact of the event on the outcome variable is estimated for each region regardless of whether the region has experienced the event or not. Then, the $r$-statistic for the region $j$ is calculated to infer statistical significance of the estimated impact between years of $T_{1}$ and $T_{2}$ as

$$
r_{j}\left(T_{1}, T_{2}\right)=\frac{\sqrt{\frac{1}{\left(T_{2}-T_{1}+1\right)} \sum_{t=T_{1}}^{T_{2}}\left(\Delta_{j t}\right)^{2}}}{\sqrt{\frac{1}{T_{0}} \sum_{t=1}^{T_{0}}\left(\Delta_{j t}\right)^{2}}}
$$

where $T_{0}$ denotes the last period before the event, and $T_{1}$ and $T_{2}$ are periods after the event such that $T_{2} \geq T_{1}$. Once $r$-statistics are obtained for all regions, they are ranked from largest to smallest and the $\mathrm{p}$-value for the $\mathrm{n}^{\text {th }}$ ranked region is calculated as $\mathrm{n}$ divided by $(\mathrm{J}+1)$. This inference method delivers statistically significant estimates (i.e., higher r-statistics and lower p-values) if estimated differences between actual and counterfactual outcomes (i.e., $\Delta_{j t}$ ) are large in the post-event period but small in the pre-event period. In other words, obtaining statistical significance requires not only observing a large impact in the post-event period but also finding a similar synthetic control region in the pre-event period.

\subsection{Application of the SCM in our Context}

We apply the method with data from the 2004-2015 period and take 2012 as the year of the event. We employ the regions where the refugee ratio was lower than 2 percent as of 2015 in the donor pool (see Table 1 for the list of these regions). We estimate the impact on various labor market outcomes separately for each gender. We employ the gender-specific values of the outcome variable of interest in the years 2006, 2009, and 2011 and the gender-specific mean values of following variables for the 2004-2011 period as predictors of the outcome variable for the associated gender in each region: the distribution of individuals over age categories (ages 18-24, 25-49, and 50-65), the distribution of individuals over educational attainment categories (illiterate and no degree, primary and secondary degree, high school degree, and college degree), the 
distribution of workers over industries (agriculture, manufacturing, construction, and service), the distribution of workers over employment types (employed, wage worker, self-employed, and employer), and the proportion of public workers.

We employ values of the outcome variable from selected pre-treatment years as predictors to control for unobserved confounders of the outcome variable, as in Abadie et al. (2010). Also, their inclusion helps us with capturing any trend in the outcome variable, which is an important feature of the labor market outcomes in this context as discussed before. We choose these years in a way that each year captures the level of the outcome variable in a different state of the economy. Particularly, the year 2006 measures the outcome in conditions before the Great Recession, the year 2009 during the recession, and the year 2011 after the recession. As we discuss later in the Robustness Section, the results are similar when the values of outcome variables from different years are used as predictors.

Our decision to analyze the impact of refugees in a short window after the initial refugee shock helps with the identification of the causal impact. To obtain causal effects, we need a variation in the refugee ratio across regions that is independent from local labor market conditions. In our context, Syrian refugees escaped from a civil war that erupted unexpectedly, and they settled mostly in regions of Turkey that are geographically close to Syria in the initial years of the conflict. As shown in Aksu et al. (2018), the distance to the border is a significant determinant of settlement patterns in Turkey of Syrian refugees observed in that period. Refugees have probably preferred geographically closer regions to minimize costs of mobility (Ferris and Kirisci, 2016). This choice also allows refugees to visit family members back in Syria. The Turkish government has also built all refugee camps in the border region, which is another reason for the predominance of refugees in these regions. Considering these plausibly exogenous factors behind the observed settlement patterns, we assume that the variation in refugee ratios across regions within Turkey is exogenous to local labor market conditions in the analyzed sample period.

\subsection{Estimation of the Effect of Development Level}

We use a regression approach to quantify the relationship between the impact of refugees and the development level of hosting regions. We initially pool values of the outcome variable of interest for all regions and their synthetic units. Let $s$ be the type of outcomes, and it takes separate values for outcomes observed in actual regions and counterfactual outcomes that are calculated for 
synthetic control regions. Let $Y_{r s t}$ denote the outcome variable in region $r$ of type $s$ at time $t$. We estimate the following regression for each outcome variable and gender separately with pooled data

(5) $\quad Y_{r s t}=\beta_{0}+\beta_{1} R_{r s t}+\beta_{2}\left(R_{r s t} * D_{r}\right)+\beta_{3} D_{r}+\delta_{r}+\delta_{t}+\varepsilon_{r s t}$,

where $R_{r s t}$ shows the refuge ratio in region $r$ at time $t$ for type $s$ outcome, $D_{r}$ denotes the development level of region $r, \delta_{r}$ is the region fixed effect, $\delta_{t}$ is the time fixed effect, and $\varepsilon_{r s t}$ is the error term. The parameter of interest is $\beta_{2}$ that captures how the impact of refugees differs by the development level of the hosting regions. Given the region fixed effects, the difference between realized refugee ratios in a region and refugee ratios calculated for its synthetic control is key for the identification of that parameter along with the variation in the development levels across regions. We calculate refugee ratios associated with each synthetic control region as the weighted sum of refugee ratios observed in the regions constituting that synthetic unit. Since none of the regions of the donor pool experienced a large influx of refugees, refugee ratios are low in synthetic units by construction. Therefore, a noticeable divergence in refugee ratios emerges after 2012 between the five regions of interest in the Syrian border and their synthetic controls. This divergence allows us to identify the impact of refugees on labor market outcomes of interest in the hosting regions. In addition, the development level across the hosting regions varies noticeably as discussed before, and that variation allows us to identify the interaction between the impact of refugees and development level of the hosting areas.

In practice, we first execute the SCM estimations and obtain values of the outcome variable of interest in synthetic control regions for the 2004-2015 period. Then, we estimate parameters of the equation (5) with the OLS. We employ values of the development level observed in 2011, a year prior to the influx of refugees, to eliminate concerns about the potential effect of refugees on the development level of host regions. We report standard errors clustered at the region level (NUTS2 level) to account for any correlation between error terms of the same region.

\section{Results}

In this section, we first present our results on the refugee impact on natives' labor market outcomes for each of the five NUTS-2 regions with the highest refugee intensity, which also display significant variation in development levels. This analysis provides us important clues about the 
relationship between development level and the refugee impact on labor market outcomes. Then, we directly test this relationship using equation (5) and data for all 26 NUTS-2 regions and their synthetic control groups for the 2004-15 period.

\subsection{Results of the Synthetic Control Analysis for the Five Focus Regions}

Figure 1 (Figure 2) shows the time evolution of employment, formal employment, informal employment, unemployment, and labor force participation of men (women) for each of our five focus regions and their synthetic controls. The weights for the regions that form the synthetic controls for each variable and each treatment region are provided in Table A2 in the Appendix. For instance, for men's employment outcome in the Adana Region, six regions form the synthetic control with the following weights: 0.223 for the Istanbul Region, 0.123 for the Izmir Region, 0.148 for the Aydin Region, 0.062 for the Antalya Region, 0.425 for the Malatya Region, and 0.021 for the Van Region.

In Figures 1 and 2, the solid line tracks the outcome for the treatment region and the dashed line denotes the outcome for its synthetic control. The estimated effects for 2015 in these graphs and their corresponding p-values are provided in Table 4 separately for each gender. The estimated effects averaged over the years 2013 to 2015 and their corresponding p-values are given in Table A3 in the Appendix. In fact, the p-values agree almost all of the time. In the discussion below, we focus on the results for 2015 as the refugee numbers for this year are substantially higher than those for the previous two years.

Before we start discussing the results, we would like to point out a few key issues in reading the results. First, the magnitudes of the refugee impact are certainly less interpretable when the fit between the treatment group and its synthetic control is not good. For instance, large differences in the post-shock period displayed in the figures could be statistically insignificant in Table 4 when the pre-shock period fit is poor (due to the method of inference given in equation 4). Second, the estimated effects for the informal sector and the formal sector do not add up to the overall employment effect in Table 4 because the regions that form the synthetic control group for a treatment region change for each variable. 


\subsubsection{Results for Men}

Table 4 indicates that the negative estimated effects on men's employment increase in magnitude as we move from the more developed to less developed regions (i.e., towards the right in the associated row of the table). As can be seen in Figure 1, for employment outcomes, the synthetic controls provide reasonably good matches for the Adana, Gaziantep, and Hatay regions but not for the less developed Sanliurfa and Mardin regions. ${ }^{21}$ No evidence of an effect in the more developed Adana and Gaziantep regions exists. The negative refugee effect displayed for the Hatay Region

in Figure 1 is statistically significant at the five percent level, as shown in Table $4 .^{22}$ While the magnitudes of the estimated negative effects for the less developed Sanliurfa and Mardin regions are high, they are not statistically significant due to the poor fits in the pre-shock period. At the same time, when we examine the average estimated effect for the 2013-15 period (Table A3 in the Appendix), rather than for 2015 only, the negative effect for the Mardin Region becomes statistically significant at the 10 percent level.

Table 4 also suggests a positive correlation between the positive impact on formal employment and level of development across regions, especially when we take into account the magnitude of the shocks across regions given in the last row of Table 4 . When we examine the graphs for formal employment of men in Figure 1, we see that the fit is very good for the Adana and Hatay regions. While no evidence of an effect exists for the Adana Region, the positive effect is marginally statistically insignificant for the Hatay Region. ${ }^{23}$ While Figure 1 displays much higher values for the Gaziantep Region than its synthetic control in the post-shock period, this is not statistically significant (in Table 4) because the fit in the pre-shock period is not good. ${ }^{24}$ While no evidence of an effect on formal employment in the two less developed regions exists, the coefficients for these less developed regions have negative signs unlike those for the other more developed three regions.

\footnotetext{
${ }^{21}$ This is presumably because the employment rates in the latter two regions are some of the lowest across the 26 NUTS-2 regions.

${ }^{22}$ The estimated effect suggests that the migrant shock lowered the male employment rate by 6.3 percentage points in the Hatay Region in 2015 (where the migrant-native ratio is 0.114 ); in other words, roughly every 11 incoming migrants displaces 6 native men. However, we need to be cautious here. Since the values of employment in the pretreatment period tend to be higher for the synthetic control, we could overestimate the negative migrant effect.

${ }^{23}$ In fact, Aksu et al. (2018) report a positive effect on formal employment of men in Turkey.

${ }^{24}$ In fact, in the plot there seems to be no change in the trend for the Gaziantep Region after the shock.
} 
No obvious correlation is observed in Table 4 between the impacts on men's informal employment and on men's participation and the level of development across regions. On the other hand, the magnitude of the positive impact of the refugee shock on unemployment rises as the level of development falls. Figure 1 indicates that the fit for the unemployment rate is reasonably well for all groups, with the exception of the Gaziantep Region. No evidence of an effect exists for the two more developed regions, Adana and Gaziantep. For the other three regions, Figure 1 suggests that the migrant shock increases the unemployment rate. While the positive impact of the refugee shock on unemployment is marginally statistically insignificant for the Hatay Region, as can be seen in Table 4, it is statistically significant at the five percent level for the two less developed regions, Sanliurfa and Mardin.

\subsubsection{Results for Women}

As can be seen in Table 4, a negative effect on employment of women is estimated in all five regions and the magnitude of this effect grows as we move from the more developed to less developed regions. However, while the fits for the pre-shock period, given in Figure 2, are very good for the Adana and Hatay regions, they are not good for the other regions. Hence, while the estimated effects for the former regions are statistically significant at the conventional levels, as can be seen in Table 4, those for the latter regions are not. At the same time, the magnitudes of the estimated effects for the two least developed regions are large and their p-values are not very high.

No obvious pattern is observed in the refugee shock on women's formal employment as we move from the more developed to less developed regions. Moreover, none of the estimated effects is statistically significant at the conventional levels as can be seen in Table $4 .{ }^{25}$ The estimated effects on informal employment of women, given in Table 4, are negative and high in absolute magnitude in all focus regions but the most developed Adana Region. However, the estimated effects for 2015 are statistically significant only for the Gaziantep and Hatay regions because the fits for the preshock period are pretty poor for the less developed Sanliurfa and Mardin regions. ${ }^{26}$

\footnotetext{
${ }^{25}$ For formal employment of women, Figure 2 illustrates a good fit for the Adana Region. The estimated effect, given in Table 4, is just below the conventional levels in terms of statistical significance. While Figure 2 also suggests a negative refugee impact for the Hatay and Mardin regions, these are not statistically significant due to the poor fits in the pre-shocks for both regions.

${ }^{26}$ For the Hatay Region, where the fit is reasonably good in the pre-shock period, the estimated effect implies that the migrant shock reduced female informal employment by 9.6 percentage points. Remember that Hatay is a region where employment of women in agriculture is high; moreover, female employment is relatively high among natives due to
} 
In terms of unemployment of women, the estimated effects, all of which have positive signs, overall grow in magnitude as we move from more developed to less developed regions. While the pre-shock fit in Figure 2 is pretty poor for the Adana and Sanliurfa regions, it is reasonably good for the other three regions. While no evidence of an effect exists for the Gaziantep Region, the estimated effects for the Hatay and Mardin regions are quite large in magnitude and just marginally statistically insignificant.

As can be seen in Table 4, the negative effect of the refugee shock on women's labor force participation also grows in magnitude as we move from more developed to less developed regions. Figure 2 also shows that the pre-shock fits for the labor force participation variable are quite good for the Adana and Hatay regions. In fact, the negative refugee effects suggested in Figure 2 are statistically significant for these two regions, as can be seen in Table 4. In addition, the estimated negative effect for the Gaziantep Region is just marginally statistically insignificant. For the two less developed regions, since the pre-shock period fits are pretty poor, we do not get statistical significance despite the very large estimated effects.

\subsection{Interaction with Development Level}

\subsubsection{Main Labor Market Outcomes}

The results in the previous section suggest a correlation between the regional patterns of the impact of the refugee shock and these regions' development level for some outcomes, including employment for men and women, formal employment for men, unemployment for men and women, and labor force participation of women. In this subsection, we formally investigate this correlation by generalizing the analysis to all regions and using the regression framework outlined in Section 4.3. In particular, using all 26 NUTS-2 regions and their synthetic control groups for the 2004-15 period, we use equation (5) to estimate the impact of the refugee shock and how this impact varies by the level of development of the hosting regions. Table 5 shows our estimates on the heterogeneity of refugee impact by regional level of development, as well as the estimates on the effects of the refugee ratio and development level. Figure 3 displays the joint effects of the coefficients of refugee ratio and the interaction of refugee ratio with the development index —at various values of the development index.

the high fraction of (more liberal) Alewite population in this region. 
Before we examine the heterogeneity by regional development, we briefly discuss the results of the refugee impact on the mean level of development. Since the development index is normalized to zero, the coefficient of the refugee ratio in Table 5 gives the refugee impact for the mean level of development. As can be seen in panel (A), the refugee shock increases men's formal employment at the expense of informal employment, as shown by difference-in-difference (Ceritoglu et al., 2017) and IV-difference-in-differences papers (del Carpio and Wagner, 2016; Aksu et al, 2018). For women, as shown in panel (B), the refugee impact lowers total employment and labor force participation, which is also consistent with the findings in del Carpio and Wagner (2016) and Aksu et al. (2018).

The estimates of the interaction term in Table 5 indicate that the refugee impact on men's employment becomes more positive as regional development rises. The joint estimates in Figure 3 in fact show that while the refugee impact on men's employment is negative at low levels of development, it is positive at high levels of development (and virtually zero at the mean level of development). Similarly, the positive refugee impact on men's formal employment at the mean level of development becomes even stronger as the development level increases. Moreover, although the interaction term is not statistically significant in the regression for unemployment, the estimated joint effects in Figure 3 at low levels of development are positive and statistically significant. In other words, for levels of development that correspond to those in the Sanliurfa and Mardin regions, the refugee shock brings about a rise in unemployment-which is consistent with the fall in employment at this development level.

For women, Table 5 shows that the refugee impact on total employment becomes more positive as the level of development rises. In fact, the estimated negative impact on total employment turns zero at a development index level of 0.5 (which is on par with the development index for the Adana Region), as can be seen from Figure 3. In a parallel manner, the refugee impact on female labor force participation also becomes more positive as the development index increases. In addition, the refugee impact on women's formal employment is also more positive for regions with higher development. In fact, the estimated joint impacts reveal a negative impact of the refugee shock on women's formal employment at low levels of development, but a positive impact at high levels of development. Finally, the estimated joint effects in Figure 3 also uncover an adverse impact on women's unemployment at low levels of development (as for men), although no such evidence exists at the mean level of development. 
In essence, for both men and women, the refugee impacts on total employment and formal employment become more positive as regional development rises. The adverse effects of the refugee shock on women's employment and labor force participation are felt in regions with low

levels of development, but these adverse effects attenuate as regional development goes up. For men, while no effect on employment is observed at the mean level of development, a positive effect emerges at high levels of development and a negative one at low levels of development. Finally, while no effect on unemployment is observed at the mean or high levels of development, evidence emerges that the refugee shock increases unemployment of both men and women at low levels of development.

\subsubsection{Outcomes by Type and Sector of Employment}

Next, we focus on the heterogeneity by distinguishing between wage and non-wage employment and examining wage employment and wages together so as to be able to interpret our results within a labor market equilibrium framework (Table 6). First, we discuss the results at the mean level development. The refugee shock increases non-wage employment at the expense of wage employment among men - a finding also reported in Aksu et al. (2018). In the informal labor market, both wages and wage employment fall for men. In the formal labor market, on the contrary, both wage employment and wages rise for men (which is also reported and discussed in length in Aksu et al. [2018]) although only the former is statistically significant at the conventional levels. For women, a negative wage effect is observed in the informal labor market - which is presumably driven by the agricultural sector, as shown in our next table and also in Aksu et al. (2018). At the same time, a negative effect on non-wage employment, that is marginally statistically insignificant, is observed.

When we examine the heterogeneity by the level of development for men, we see that the positive effect on non-wage employment at the mean level of development becomes even stronger as regional development rises. Presumably, the boom in self-employment in the service sector is more pronounced in more developed regions - for which our analysis by sector of employment provides support. In addition, the interaction term for wages is positive, implying that the refugee impact on wages becomes more positive in more developed regions. When we examine the effect by level of development in the formal and informal sector separately, overall, we find that the above mentioned negative effects in the informal sector and the positive effects in the formal sector both 
become stronger in magnitude in the more developed regions. In other words, the transition of native men from informal to formal employment becomes more pronounced among wage workers as regional development rises. In addition, Appendix Figure A1 shows that while the refugee impact on men's wages in the formal sector is positive at high levels of development, it is negative at very low levels of development.

For women, the refugee impact on both wage employment and wages becomes much stronger as regional development rises, which is driven by the results in the formal sector. In fact, while the refugee effects on women's wage employment and wages are negative at low levels of development, they are positive at high levels of development (Appendix Figure A1). In addition, as for men, the refugee impact on the informal sector gets more negative and the refugee impact on the formal sector becomes more positive as the level of regional development increases. Hence, the transition of wage workers from the informal to the formal sector also accelerates for women as regional development increases.

In essence, the impact of the refugee shock on non-wage workers among men and wage workers among women (both in terms of employment and wages) becomes more positive as regional development rises. Moreover, the transition from the informal to the formal sector accelerates both for men and women among wage workers as we move from less developed to more developed regions.

Table 7 shows our estimation results by sector of employment. In terms of the refugee impact at the mean level of development, the estimates indicate a negative impact on men's employment in construction. In the manufacturing and service sector, an increase in formal employment at the expense of informal employment is also observed for men. The interaction terms show that as the level of development goes up, the refugee impact becomes more positive in formal employment and more negative in informal employment both in the manufacturing and service sector and for both men and women. This finding is consistent with that in Table 6. In fact, at high levels of development, the refugee impact on men's employment in the service sector and women's employment both in the manufacturing and service sectors becomes positive (Appendix Figure A2). Moreover, the negative impact on men's employment in the construction sector, which is overwhelmingly informal employment dominated, becomes even more negative as regional development rises. 


\subsection{Potential Mechanisms}

Aksu et al. (2018) show that the adverse effects of Syrian refugees on natives' labor market outcomes are mostly observed in agriculture, construction, and among informal workers in manufacturing and services - who tend to be younger and less-educated. As pointed out in Section 3 , the five regions experiencing the influx of refugees differ in terms of their demographic and sectoral composition such that people in less developed regions, Sanliurfa and Mardin, are younger and less educated and more likely to work in agriculture and the construction sector. Therefore, the refugee impact on native employment is expected to be more adverse in less developed regions - where young and less-educated refugees are closer substitutes to natives. The empirical findings shown in the previous section are consistent with this explanation. On the other hand, job opportunities in the formal service and manufacturing sectors are more prevalent in developed regions. Thus, natives crowded out of agricultural and construction jobs might find new positions in these sectors. Our finding that native employment in formal service and manufacturing jobs increases in developed regions after the arrival of refugees (Figure A2) supports this claim.

Akgündüz et al. (2020) find evidence for expansion of existing firms and establishment of new firms as a result of the refugee shock using firm level data and regional variation in the ratio of refugees to natives. However, the capacity of generating new jobs might differ across regions based on the development level. Attracting new investments and establishing new firms might be easier in developed regions. We examine this issue using data on firm openings provided by the Union of Chambers and Commodity Exchanges of Turkey for the 2009-15 period. Indeed, our tabulations indicate supporting evidence for the fact that new firm openings are higher in more developed regions. As shown in the left panel of Figure 4, the number of new firms increased noticeably in the Adana (124\% from 2012 to 2015), Gaziantep (89\%) and Hatay (88\%) regions after 2012, whereas it stayed relatively stable in the less developed Sanliurfa and Mardin regions. As the number of firm closures remained unaffected, the number of firms increased only in the developed Adana, Gaziantep, and Hatay regions after the influx of Syrian refugees as shown in the right panel of Figure 4. New firms presumably increased the demand for labor, which attenuated adverse effects of refugees on native employment as implied by our findings in the previous section. 


\subsection{Robustness}

\subsubsection{Alternative Choice of Predictors}

In this subsection, we discuss the robustness of our results to our specification. The SCM leaves the choice of predictors to practitioners. ${ }^{27}$ For robustness purposes, we explore the sensitivity of our estimates to different selections of years as predictors for values of the outcome variable. Appendix Table A4 shows the effects of the refugee ratio and its interaction with the development index on main labor market outcomes where the outcome variable for synthetic units is obtained from SCM estimates relying on different sets of predictors.

Panel A of the table presents results obtained from the SCM specification including values of the outcome variable from all years of the pre-treatment period without including any other predictors. As well-documented in Kaul et al. (2015), it is not possible to include another set of predictors when the value of the outcome variable from each year in the pre-treatment period is used. The estimates in Appendix Table A4 are quite similar to those with the baseline specification presented in Table 5. The transition of informal to formal employment becomes more apparent in developed regions for both men and women, and the effect of refugees on total employment becomes more positive as the development level increases.

Ferman (2020) suggests using the values of the outcome variable observed in odd- or evennumbered years to address concerns about cherry-picking in selecting the years of observations. We adopt this suggestion as an additional robustness check. Panel B in Appendix Table A4 presents results by using the values of the outcome variable only from odd-numbered years along with the set of other predictors employed in the baseline specification, whereas Panel C presents results from the specification with even-numbered years and the other predictors. Both specifications provide estimates that are consistent with our main findings, with the only exception of the interaction between refugee ratio and development becoming not statistically significant for formal employment of women in Panel C.

\footnotetext{
${ }^{27}$ Borjas (2017) highlights this feature as a source of arbitrariness in the SCM. In fact, he finds different wage impacts of the Mariel boatlift using different sets of control variables. In our context, however, the sample size of the microlevel dataset is much higher, resulting in less volatility in the outcomes. Moreover, the magnitude of the refugee shock is larger in our three regions with the highest refugee to native ratio. These two features yield the estimation of the refugee shock relatively more easily in our context.
} 


\subsubsection{Exclusion of Outlier Values of Development Level}

In another set of robustness checks, we exclude the regions with outlier values of development level. As can be seen from Table 1, the development level of the most developed region, the Istanbul Region, is 4.515 standard deviations away from the mean. The development index of the Ankara and Izmir regions, is 2.838 and 1.972 standard deviations away from the mean respectively, whereas the development index for the least developed region is closer to the mean, at -1.493 standard deviations. Hence, we first check the robustness of our main findings to the exclusion of only the Istanbul Region. Second, we also exclude the Ankara and Izmir regions, in which case the range of the development index is $[-1.493,1.267]$. The results from the estimation of equation (5) are given in Table A5 in the Appendix and the estimates on the effect of the refugee ratio at various levels of the development index are illustrated in Figures A3 and A4 in the Appendix for the two different exclusion choices.

Table A5 shows that all the main findings remain except for the positive interaction term on women's employment and labor force participation with either type of exclusion. Nonetheless, the coefficient magnitude of the interaction term on women's employment is similar to the baseline estimate in Table 5. At the same time, the interaction terms on both men's and women's unemployment becomes statistically significant; the refugee impact on unemployment is less adverse at high levels of development, which is also consistent with the overall less adverse effects of refugees in more developed regions. In fact, when all three most developed regions are excluded, the refugee impact on both men's and women's unemployment becomes negative at high levels of development. In addition, Figures A3 and A4 show that, certain effects-such as the positive effects on men's employment and formal employment-become more precisely estimated with the exclusion of the most developed regions.

\section{Conclusion}

In this study, we examine how the impact of the massive inflow of Syrian refugees into Turkey on natives' labor market outcomes varies by the level of development of hosting regions. Certain features of our study aid our identification significantly. First, different regions of the country that received high levels of refugees exhibit significant variation in development levels. Second, we 
can hold other factors such as labor market institutions and legal framework constant — within our analysis in a single country with common institutions.

Our findings show that the impact of the refugees on both men's and women's labor market outcomes becomes more positive as the development level rises. In particular, for men, this is observed in employment, formal employment, non-wage employment, and wages among wage workers. For women, this is observed in employment, formal employment, labor force participation, and in both employment and wages among wage workers. Moreover, for women, the negative effects of the refugee shock on employment and labor force participation observed at the mean level of development vanishes at high levels of development. In addition, the transition from informal employment to formal employment — particularly in the manufacturing and service sectors, found in the mean level of development - becomes more pronounced for both men and women as the level of development rises.

These findings show that across regions that exhibit significant variation in development level within the same country - one with a strong central government and uniform labor and legal framework across regions - regions with lower levels of development are more adversely affected by the refugee shock. This has important implications for the optimal allocation of refugees both within countries and across countries (especially among those that could aim for a common refugee policy due to economic and political partnerships, such as the EU).

In the optimal distribution of refugees across regions of a given country, our findings suggest the following. First, policies restricting the within-country mobility of refugees, which prevents the migration of refugees to more developed regions of the country, would be detrimental for natives' labor market outcomes. Second, given the fact that the initial location of camps could be an important determinant of the long-term settlement patterns of refugees (which is the case in Turkey), it is crucial to choose the initial location of camps wisely so that the effects of refugees can be better absorbed. Third, our findings also imply that refugee shocks would exacerbate inequality across regions within the same host country.

In the optimal distribution across countries, our findings imply that in the neighboring countries where most refugees flee-most of which are also developing countries - the labor market outcomes of natives would be more adversely affected compared to those of natives in developed countries. However, developed countries host a much smaller share of the refugees around the 
world. In the same manner, we might expect less adverse effects in the wealthier EU countries than other member countries, if the EU countries were to accept refugees in proportion to their populations. While our findings come from a certain country with its own labor market institutions, such as the existence of a sizable informal sector, as we move to more developed regions of Turkey, the size of the informal sector diminishes substantially and demographic and labor market outcomes become similar to those of more developed countries.

The integration of refugees into society in general have, obviously, costs other than the impact on employment and wages of natives. As illustrated by Dustmann and Preston (2007), in addition to migrants' labor market effects, their fiscal impact and cultural distance are other major concerns for natives. The aversion to immigrants in many developed countries has also strong cultural elements (Dustmann and Preston, 2007; Card et al, 2012). In fact, in the deal between the EU and Turkey, a tacit reason for keeping them in Turkey by compensating the Turkish government is their alleged "cultural proximity" to Turkey. While refugees might displace fewer natives in the labor markets of developed countries, they might be more likely to remain unemployed and live on the welfare scheme there due to the relatively scarce unskilled jobs-increasing the costs to the fiscal coffers. However, the empirical evidence is mixed on whether or not the fiscal effect of migrants over their lifetime in these countries is positive (see, e.g., Auerbach and Oreopoulos, 1999; Lee and Miller, 2000; Storesletten, 2000; Chojnicki et al, 2011; Kurdar, 2012). In this backdrop, this study shows that the residents of developed countries also have less to lose in the labor market from the arrival of refugees compared to the residents of less developed neighboring countries. 


\section{References}

Abadie, A., Diamond, A., \& Hainmueller, J. (2010). Synthetic Control Methods for Comparative Case Studies of Aggregate Interventions: Estimating the Effect of California's Tobacco Control Program. Journal of the American Statistical Association 105(490), 493-505.

Abadie, A., \& Gardeazabal, J. (2003). The Economic Costs of Conflict: A Case Study of the Basque Country. American Economic Review 93(1), 113-132.

Akgündüz Y.E. \& Torun H. (2020). Two and a Half Million Syrian Refugees, Tasks and Capital Intensity. Journal of Development Economics 145:

Akgündüz Y.E, Bağır, Y.K., Cilasun, S.M. \& Kırdar, M.G. (2020). Consequences of a Massive Refugee Influx on Firm Performance ad Market Structure, IZA DP 13953.

Aksu, E., Erzan, R., \& Kirdar, M.G. (2018). The Impact of Mass Migration of Syrians on the Turkish Labor Market. IZA DP No. 12050.

Angrist, J.D., \& Kugler, A. (2003). Protective or Counter-Productive? Labor Market Institutions and the Effect of Immigration on EU Natives. Economic Journal 113: F302-F331.

Auerbach, A. J \& Oreopoluos, P. (1999) Analyzing the Fiscal Impact of U.S. Immigration. American Economic Review 89, 176-80.

Aydemir, A., \& Kirdar, M.G. (2017) Quasi-Experimental Impact Estimates of Immigrant Labor Supply Shocks: The Role of Treatment and Comparison Group Matching and Relative Skill Composition. European Economic Review 98: 282-315.

Aydemir, A. \& Yazici, H. (2019). Intergenerational Education Mobility and the Level of Development. European Economic Review 116, 160-185.

Bakış, O. \& Polat, S. (2021). Wage Inequality Dynamics in Turkey. Mimeo.

Becker, S. \& Ferrara, A. (2019). Consequences of Forced Migration: A Survey of Recent Findings. Labour Economics 59: 1-16.

Borjas, G.J. (2017). The Wage Impact of the Marielitos: A Reappraisal. Industrial and Labor Relations Review, 70(5), 1077-1110.

Borjas, G.J. \& Monras J. (2016). The Labor Market Consequences of Refugee Supply Shocks. 
Economic Policy, 32, 361-413.

Bozzoli, C., Bruck, T. \& Wald, N. (2013). Self-employment and Conflict in Colombia. Journal of Conflict Resolution 57(1): 117-142.

Bryant, J. \& Rukumnuaykit (2013). The Labour Market Impacts of Immigration to Developing Countries: Evidence from a Registration Campaign in Thailand. Journal of Development Studies 49(6): 785-800.

Calderon-Mejia, V. \& Ibanez A.M. (2016). Labour Market Effects of Migration-Related Supply Shocks: Evidence from Internal Refugees in Colombia. Journal of Economic Geography 16(3); 695-713.

Card, D. (1990). The Impact of the Mariel Boatlift on the Miami Labor Market. Industrial and Labor Relations Review, 43, 245-257.

Card, D., Dustmann, C., \& Preston, I. (2012). Immigration, Wages, and Compositional Amenities. Journal of the European Economic Association 10(1), 78-119.

Ceritoğlu, E., Yüncüler, H.B., Torun, H., \& Tümen, S. (2017). The Impact of Syrian Refugees on Natives' Labor Market Outcomes in Turkey: Evidence from a Quasi-Experimental Design. IZA Journal of Labor Policy 6: Article number: 5.

Chojnicki, X., Docquier, F., \& Ragot, L. (2011). Should the US have locked heaven's door? Reassessing the benefits of postwar immigration. Journal of Population Economics, 24(1), 317-359.

Cohen-Goldner, S., \&. Paserman, M.D (2011). The Dynamic Impact of Immigration on Natives' Labor Market Outcomes: Evidence from Israel. European Economic Review 55, 1027-1045.

D'Amuri F. \& Peri G. (2014). Immigration, Jobs, and Employment Protection: Evidence from Europe before and during the Great Recession. Journal of the European Economic Association $12,432-464$.

Dayığlu, M. \& Kırdar M.G. (2010). Determinants of and Trends in Labor Force Participation of Women in Turkey. State Planning Organization of the Republic of Turkey and World Bank, Welfare and Social Policy Analytical Work Program, Working Paper Number 5, Ankara.

Del Carpio, X., \& Wagner, M. (2016). The Impact of Syrian Refugees on the Turkish Labor 
Market. Policy Research Working Paper Series 7402.

Dustmann, C. \& Preston, I. (2007). Racial and Economic Factors in Attitudes to Immigration. The B.E. Journal of Economic Analysis \& Policy, 7(1), 1-41.

Eryurt, M.A. (2017) Türkiye'ye Göç: Demografik Durum ve Etkiler. Hacettepe University, Institute of Population Studies, PowerPoint Slides.

Ferman, B., Cristine P., \& Possebom, V. (2020). Cherry picking with synthetic controls. Journal of Policy Analysis and Management, 39(2), 510-532.

Ferris, E. and K. Kirişci (2016) The Consequences of Chaos: Syria's Humanitarian Crisis and the Failure to Protect, Brookings Institution Press, Washington, D.C.

Foged, M., \& Peri, G. (2016). Immigrants' Effect on Native Workers: New Analysis on Longitudinal Data. American Economic Journal: Applied Economics 8(2), 1-34.

Friedberg, R. M. (2001). The Impact of Mass Migration on the Israeli Labor Market. Quarterly Journal of Economics, 116, 1373-1408.

Glitz, A. (2012). The Labor Market Impact of Immigration: A Quasi-Experiment Exploiting Immigrant Location Rules in Germany. Journal of Labor Economics, 30, 175-213.

Hacettepe University Institute of Population Studies (2019a). 2018 Türkiye Nüfus ve Sağlık Araştırması Suriyeli Göçmen Örneklemi, Temel Bulgular. Hacettepe Üniversitesi Nüfus Etütleri Enstitüsü, T.C. Cumhurbaşkanlığı Strateji ve Bütçe Başkanlığı ve TÜBİTAK, Ankara, Türkiye.

Hacettepe University Institute of Population Studies (2019b). 2018 Türkiye Nüfus ve Sağlık Araştırması. Hacettepe Üniversitesi Nüfus Etütleri Enstitüsü, T.C. Cumhurbaşkanlığı Strateji ve Bütçe Başkanlığı ve TÜBİTAK, Ankara, Türkiye.

Hunt, J. (1992). The Impact of the 1962 Repatriates from Algeria on the French Labor Market. Industrial and Labor Relations Review, 43, 556-572.

Kaul, A., Klößner, S., Pfeifer, G., \& Schieler, M. (2015). Synthetic control methods: Never use all pre-intervention outcomes together with covariates. Working paper.

Kirdar, M.G. (2012). Estimating the Impact of Immigrants on the Host Country Social Security System When Return Migration is an Endogenous Choice. International Economic Review 
53(2), 453-486.

Lee, R. \& Miller, T. (2000). Immigration, Social Security, and Broader Fiscal Impacts. American Economic Review 90, 350-354.

Malaeb, B. \& Wahba, J. (2018) Impact of Refugees on Immigrants' Labor Market Outcomes. Economic Research Forum, Working Paper No. 1194.

Maystadt, J-F. \& Verwimp P. (2014). Winners and Losers among a Refugee-Hosting Population. Economic Development and Cultural Change 62(4): 769-809.

MiGazin (2015). Syrer offenbar gebildeter als andere Flüchtlinge. 17 September 2015. http://www.migazin.de/2015/09/17/syrer-offenbar-gebildeter-als-andere-fluechtlinge/

Morales J.S. (2017). The Impact of Internal Displacement on Destination Communities: Evidence from the Colombian Conflict. Journal of Development Economics 131: 132-150.

Ottaviano, G., \& Peri, G. (2012). Rethinking the Effect of Immigration on Wages. Journal of the European Economic Association 10(1), 152-97.

Peri, G. \& Sparber, C. (2009). Task Specialization, Immigration and Wages. American Economic Journal: Applied Economics, 1, 135-169.

Peri, G. \& Yasenov, V. (2019). The Labor Market Effects of a Refugee Wave: Applying the Synthetic Control Method to the Mariel Boatlift. Journal of Human Resources 54(2): 267309.

Storesletten, K. (2000) Sustaining Fiscal Policy Through Immigration. Journal of Political Economy 108, 300-23.

TDEMA (2016). Türkiye'deki Suriyeli Mültecilerin Sağlık Durumu Araştırması. October 2016.

Tunali, I., Kirdar, M.G., \& Dayioglu, M. (2019). Female Labor Force Participation in Turkey: A Synthetic Control (Panel) Analysis, 1988-2013. IZA DP No. 12844.

Turkish Ministry of Development (2013). Illerin ve Bolgelerin Sosyo-ekonomik Gelismislik Siralamasi Arastirmasi.

UNHCR (2018) Syria Regional Refugee Rense. http://data.unhcr.org/syrianrefugees/regional.php 
UNHCR (2021a). Figures at a Glance. Retrieved from https://www.unhcr.org/en-us/figures-at-aglance.html.

UNHCR (2021b). Syrian Regional Refugee Response. Retrieved from http://data2.unhcr.org/en/situations/syria.

Verme, P., \& Schuettler, K. (2021). The impact of forced displacement on host communities: A review of the empirical literature in economics. Journal of Development Economics 150, 102606. 


\section{Tables and Figures}

Table 1: Key Information on NUTS-2 Regions

\begin{tabular}{llrrrrr}
\hline NUTS-2 & & Population, & Development & \multicolumn{3}{c}{ Migrant to Native Ratio } \\
\cline { 5 - 7 } Region & Major City & 2015 & Index, 2011 & 2013 & 2014 & 2015 \\
\hline & & & & & & \\
1 & Istanbul & $14,657,434$ & 4.515 & 0.002 & 0.012 & 0.018 \\
2 & Tekirdag & $1,687,420$ & 0.774 & 0.000 & 0.000 & 0.006 \\
3 & Balikesir & $1,700,029$ & 0.513 & 0.000 & 0.000 & 0.002 \\
4 & Izmir & $4,168,415$ & 1.972 & 0.000 & 0.002 & 0.015 \\
5 & Aydin & $2,955,825$ & 0.826 & 0.000 & 0.001 & 0.005 \\
6 & Manisa & $3,013,892$ & 0.244 & 0.000 & 0.000 & 0.002 \\
7 & Bursa & $3,881,624$ & 1.267 & 0.001 & 0.003 & 0.016 \\
8 & Kocaeli & $3,617,728$ & 1.053 & 0.001 & 0.003 & 0.005 \\
9 & Ankara & $5,270,575$ & 2.838 & 0.001 & 0.003 & 0.007 \\
10 & Konya & $2,372,740$ & 0.495 & 0.002 & 0.010 & 0.015 \\
11 & Antalya & $2,968,561$ & 1.231 & 0.000 & 0.002 & 0.002 \\
$\mathbf{1 2}$ & Adana & $\mathbf{3 , 9 2 8 , 3 8 8}$ & $\mathbf{0 . 5 2 1}$ & $\mathbf{0 . 0 0 5}$ & $\mathbf{0 . 0 1 5}$ & $\mathbf{0 . 0 5 0}$ \\
$\mathbf{1 3}$ & Hatay & $\mathbf{3 , 1 4 2 , 9 9 0}$ & $\mathbf{- 0 . 2 7 3}$ & $\mathbf{0 . 0 2 9}$ & $\mathbf{0 . 0 5 0}$ & $\mathbf{0 . 1 1 4}$ \\
14 & Kirikkale & $1,515,228$ & -0.125 & 0.000 & 0.001 & 0.004 \\
15 & Kayseri & $2,379,113$ & 0.113 & 0.000 & 0.002 & 0.014 \\
16 & Zonguldak & $1,023,593$ & 0.193 & 0.000 & 0.000 & 0.000 \\
17 & Kastamonu & 757,711 & -0.219 & 0.000 & 0.000 & 0.001 \\
18 & Samsun & $2,721,221$ & 0.000 & 0.000 & 0.000 & 0.001 \\
19 & Trabzon & $2,572,850$ & -0.076 & 0.000 & 0.000 & 0.001 \\
20 & Erzurum & $1,063,789$ & -0.375 & 0.000 & 0.000 & 0.000 \\
21 & Agri & $1,131,570$ & -1.361 & 0.000 & 0.000 & 0.001 \\
22 & Malatya & $1,700,468$ & -0.245 & 0.003 & 0.003 & 0.009 \\
23 & Van & $2,124,349$ & -1.493 & 0.000 & 0.001 & 0.001 \\
$\mathbf{2 4}$ & Gaziantep & $\mathbf{2 , 6 6 5 , 2 6 5}$ & $\mathbf{- 0 . 0 5 5}$ & $\mathbf{0 . 0 4 9}$ & $\mathbf{0 . 0 7 2}$ & $\mathbf{0 . 1 3 4}$ \\
$\mathbf{2 5}$ & Sanliurfa & $\mathbf{3 , 5 4 6 , 5 1 6}$ & $\mathbf{- 1 . 1 4 7}$ & $\mathbf{0 . 0 2 6}$ & $\mathbf{0 . 0 3 9}$ & $\mathbf{0 . 0 8 6}$ \\
$\mathbf{2 6}$ & Mardin & $\mathbf{2 , 1 7 3 , 7 5 9}$ & $\mathbf{- 1 . 3 2 8}$ & $\mathbf{0 . 0 1 5}$ & $\mathbf{0 . 0 3 0}$ & $\mathbf{0 . 0 4 4}$ \\
\hline
\end{tabular}

Notes: The number of Syrian refugees for 2013 comes from AFAD. Although the numbers for provinces without camps are not reported, it is known that 80,000 Syrians were residing in those provinces that year. Thus, we estimate the numbers for provinces without information by distributing these 80,000 Syrians based on the relative ratios in these provinces in 2014 . The numbers for 2014 are taken from Erdogan (2014), who draws on information from AFAD and the Ministry of Interior. The numbers for 2015 are provided by the Ministry of Interior Directorate General of Migration Management. The native populations are taken form TURKSTAT, which are publicly available. All numbers are aggregated at NUTS-2 level. 
Table 2: Demographic Characteristics in the Pre-Refugee Period

\begin{tabular}{|c|c|c|c|c|c|c|}
\hline & Adana & Gaziantep & Hatay & Sanliurfa & Mardin & Turkey \\
\hline \multicolumn{7}{|l|}{ Panel B: Men } \\
\hline \multicolumn{7}{|l|}{ Educational Levels } \\
\hline No Degree & 0.083 & 0.088 & 0.120 & 0.239 & 0.184 & 0.060 \\
\hline Primary or Secondary School & 0.558 & 0.610 & 0.620 & 0.503 & 0.512 & 0.572 \\
\hline High School & 0.248 & 0.213 & 0.190 & 0.193 & 0.235 & 0.248 \\
\hline College & 0.110 & 0.089 & 0.070 & 0.065 & 0.069 & 0.120 \\
\hline \multicolumn{7}{|l|}{ Age Groups } \\
\hline $18-24$ & 0.185 & 0.191 & 0.228 & 0.254 & 0.252 & 0.182 \\
\hline $25-49$ & 0.622 & 0.617 & 0.615 & 0.607 & 0.614 & 0.622 \\
\hline $50-64$ & 0.193 & 0.192 & 0.157 & 0.139 & 0.134 & 0.197 \\
\hline \multicolumn{7}{|l|}{ Panel B: Women } \\
\hline \multicolumn{7}{|l|}{ Educational Levels } \\
\hline No Degree & 0.238 & 0.310 & 0.416 & 0.674 & 0.625 & 0.223 \\
\hline Primary or Secondary School & 0.503 & 0.509 & 0.449 & 0.224 & 0.273 & 0.529 \\
\hline High School & 0.188 & 0.137 & 0.099 & 0.078 & 0.080 & 0.166 \\
\hline College & 0.071 & 0.044 & 0.037 & 0.025 & 0.022 & 0.082 \\
\hline \multicolumn{7}{|l|}{ Age Groups } \\
\hline $18-24$ & 0.198 & 0.204 & 0.241 & 0.287 & 0.293 & 0.195 \\
\hline $25-49$ & 0.607 & 0.613 & 0.598 & 0.578 & 0.570 & 0.604 \\
\hline $50-64$ & 0.195 & 0.182 & 0.161 & 0.135 & 0.137 & 0.200 \\
\hline
\end{tabular}

Notes: The 2004-2011 Turkish HLSF. The sample is restricted to people who are aged between 18 and 64. The statistics are calculated, using person weights that are provided in the data. Region names refer to regions in NUTS-2 level division. 
Table 3: Structure of the Labor Market in the Pre-Refugee Period

\begin{tabular}{|c|c|c|c|c|c|c|}
\hline & Adana & Gaziantep & Hatay & Sanliurfa & Mardin & Turkey \\
\hline \multicolumn{7}{|l|}{ Panel A: Men } \\
\hline Employed & 0.689 & 0.685 & 0.671 & 0.593 & 0.609 & 0.709 \\
\hline Employed in Formal Jobs & 0.367 & 0.300 & 0.352 & 0.187 & 0.241 & 0.446 \\
\hline Employed in Informal Jobs & 0.322 & 0.385 & 0.319 & 0.406 & 0.369 & 0.262 \\
\hline Labor Force Participation & 0.810 & 0.818 & 0.794 & 0.688 & 0.705 & 0.795 \\
\hline Unemployment Rate & 0.175 & 0.195 & 0.183 & 0.160 & 0.157 & 0.108 \\
\hline \multicolumn{7}{|l|}{ Employment by Industry } \\
\hline Agriculture & 0.199 & 0.179 & 0.204 & 0.231 & 0.210 & 0.165 \\
\hline Construction & 0.088 & 0.094 & 0.099 & 0.109 & 0.102 & 0.081 \\
\hline Manufacturing, informal jobs & 0.059 & 0.117 & 0.059 & 0.048 & 0.039 & 0.050 \\
\hline Manufacturing, formal jobs & 0.108 & 0.163 & 0.147 & 0.031 & 0.063 & 0.175 \\
\hline Service, informal jobs & 0.195 & 0.206 & 0.187 & 0.328 & 0.297 & 0.149 \\
\hline Service, formal jobs & 0.351 & 0.241 & 0.305 & 0.253 & 0.288 & 0.380 \\
\hline \multicolumn{7}{|l|}{ Employment by Type } \\
\hline Non-Wage Workers & 0.361 & 0.367 & 0.369 & 0.423 & 0.401 & 0.358 \\
\hline Wage Workers & 0.639 & 0.633 & 0.631 & 0.577 & 0.599 & 0.642 \\
\hline Wage Workers, informal jobs & 0.255 & 0.290 & 0.251 & 0.314 & 0.291 & 0.169 \\
\hline Wage Workers, formal jobs & 0.384 & 0.343 & 0.380 & 0.263 & 0.308 & 0.472 \\
\hline \multicolumn{7}{|l|}{ Mean of Log Wages for } \\
\hline Wage Workers & 1.246 & 1.084 & 1.256 & 1.231 & 1.215 & 1.413 \\
\hline Wage Workers, informal jobs & 0.759 & 0.726 & 0.752 & 0.791 & 0.692 & 0.945 \\
\hline Wage Workers, formal jobs & 1.516 & 1.352 & 1.511 & 1.695 & 1.664 & 1.559 \\
\hline \multicolumn{7}{|l|}{ Panel B: Women } \\
\hline Employed & 0.225 & 0.125 & 0.226 & 0.082 & 0.074 & 0.252 \\
\hline Employed in Formal Jobs & 0.079 & 0.039 & 0.046 & 0.023 & 0.029 & 0.104 \\
\hline Employed in Informal Jobs & 0.146 & 0.086 & 0.180 & 0.059 & 0.045 & 0.148 \\
\hline Labor Force Participation & 0.285 & 0.139 & 0.260 & 0.087 & 0.082 & 0.287 \\
\hline Unemployment Rate & 0.211 & 0.097 & 0.132 & 0.059 & 0.105 & 0.121 \\
\hline \multicolumn{7}{|l|}{ Employment by Industry } \\
\hline Agriculture & 0.396 & 0.447 & 0.570 & 0.632 & 0.530 & 0.419 \\
\hline Construction & 0.008 & 0.009 & 0.002 & 0.002 & 0.005 & 0.007 \\
\hline Manufacturing, informal jobs & 0.073 & 0.098 & 0.076 & 0.019 & 0.021 & 0.063 \\
\hline Manufacturing, formal jobs & 0.039 & 0.048 & 0.023 & 0.003 & 0.012 & 0.089 \\
\hline Service, informal jobs & 0.195 & 0.145 & 0.157 & 0.076 & 0.107 & 0.114 \\
\hline Service, formal jobs & 0.289 & 0.253 & 0.172 & 0.267 & 0.325 & 0.308 \\
\hline \multicolumn{7}{|l|}{ Employment by Type } \\
\hline Non-Wage Workers & 0.439 & 0.484 & 0.638 & 0.510 & 0.505 & 0.481 \\
\hline Wage Workers & 0.561 & 0.516 & 0.362 & 0.490 & 0.495 & 0.519 \\
\hline Wage Workers, informal jobs & 0.255 & 0.224 & 0.182 & 0.223 & 0.166 & 0.141 \\
\hline Wage Workers, formal jobs & 0.306 & 0.292 & 0.180 & 0.267 & 0.329 & 0.378 \\
\hline \multicolumn{7}{|l|}{ Mean of Log Wages for } \\
\hline Wage Workers & 1.274 & 1.320 & 1.263 & 1.426 & 1.529 & 1.471 \\
\hline Wage Workers, informal jobs & 0.659 & 0.635 & 0.575 & 0.643 & 0.545 & 0.868 \\
\hline Wage Workers, formal jobs & 1.669 & 1.658 & 1.726 & 1.885 & 1.949 & 1.651 \\
\hline
\end{tabular}

Notes: The 2004-2011 Turkish HLSF. The sample is restricted to people who are aged between 18 and 64. The statistics are calculated, using person weights that are provided in the data. Region names refer to regions in NUTS-2 level division. 
Table 4: Effects of Refugees on Main Labor Market Outcomes for 2015

\begin{tabular}{|c|c|c|c|c|c|c|}
\hline & & \multicolumn{5}{|c|}{ Region } \\
\hline & & Adana & Gaziantep & Hatay & Sanliurfa & Mardin \\
\hline \multicolumn{7}{|c|}{ Employment } \\
\hline \multirow[t]{2}{*}{ Men } & Effect & 0.013 & -0.004 & -0.063 & -0.056 & -0.107 \\
\hline & p-value & 0.500 & 0.864 & 0.091 & 0.591 & 0.273 \\
\hline \multirow[t]{2}{*}{ Women } & Effect & -0.040 & -0.104 & -0.138 & -0.106 & -0.193 \\
\hline & $\mathrm{p}$-value & 0.091 & 0.182 & 0.045 & 0.273 & 0.182 \\
\hline \multicolumn{7}{|c|}{ Formal Employment } \\
\hline \multirow{2}{*}{ Men } & Effect & 0.025 & 0.075 & 0.048 & -0.020 & -0.014 \\
\hline & p-value & 0.545 & 0.364 & 0.136 & 0.864 & 0.864 \\
\hline \multirow[t]{2}{*}{ Women } & Effect & -0.027 & 0.022 & -0.023 & 0.004 & -0.018 \\
\hline & p-value & 0.182 & 0.500 & 0.455 & 0.909 & 0.545 \\
\hline \multicolumn{7}{|c|}{ Informal Employment } \\
\hline \multirow[t]{2}{*}{ Men } & Effect & 0.010 & -0.090 & -0.052 & 0.025 & -0.020 \\
\hline & p-value & 0.227 & 0.091 & 0.091 & 0.455 & 0.727 \\
\hline \multirow[t]{2}{*}{ Women } & Effect & 0.012 & -0.081 & -0.096 & -0.057 & -0.113 \\
\hline & $\mathrm{p}$-value & 0.500 & 0.091 & 0.045 & 0.273 & 0.136 \\
\hline \multicolumn{7}{|c|}{ Unemployment Rate } \\
\hline \multirow[t]{2}{*}{ Men } & Effect & -0.004 & -0.002 & 0.050 & 0.092 & 0.140 \\
\hline & $\mathrm{p}$-value & 0.818 & 0.955 & 0.136 & 0.045 & 0.045 \\
\hline \multirow[t]{2}{*}{ Women } & Effect & 0.002 & 0.011 & 0.098 & 0.045 & 0.161 \\
\hline & $\mathrm{p}$-value & 0.909 & 0.727 & 0.136 & 0.455 & 0.136 \\
\hline \multicolumn{7}{|c|}{ Labor Force Participation } \\
\hline \multirow[t]{2}{*}{ Men } & Effect & -0.009 & -0.002 & -0.032 & 0.009 & -0.004 \\
\hline & $\mathrm{p}$-value & 0.409 & 0.818 & 0.045 & 0.773 & 0.864 \\
\hline \multirow[t]{2}{*}{ Women } & Effect & -0.053 & -0.118 & -0.132 & -0.100 & -0.187 \\
\hline & $\mathrm{p}$-value & 0.091 & 0.136 & 0.045 & 0.409 & 0.182 \\
\hline \multicolumn{2}{|c|}{ Refugee Ratio x100 in 2015} & 5.0 & 13.4 & 11.4 & 8.6 & 4.4 \\
\hline
\end{tabular}

Notes: The table shows the difference between the labor market outcome of the treated and the synthetic unit in 2015 separately for men and women in each region. The corresponding p-values are provided below the magnitudes in italics. The synthetic units are constructed by matching over the age distribution of population (ages 18-24, 25-49, and 50-65), the educational distibution of population (illiterate and no degree, primary and secondary degree, high school degree, college degree), the sectoral distribution of workers (agriculture, manufacturing, construction, and service), the employment types of workers (employed, wage worker, self-employed, and employer), the proportion of public workers, and the value of the dependent variable in years 2006, 2009, and 2011. 
Table 5: Heterogeneity in the Effects of Refugees on Main Labor Market Outcomes by Regional Development

\begin{tabular}{lccccc}
\hline & Employed & Formal & Informal & Unemployment & LFP \\
\cline { 2 - 6 } Panel A: Men & & & & & \\
Refugee Ratio x100 & -0.0008 & $0.0051^{* *}$ & $-0.0050^{* *}$ & 0.0008 & -0.0004 \\
& $(0.001)$ & $(0.002)$ & $(0.002)$ & $(0.003)$ & $(0.001)$ \\
Interaction of Refugee Ratio x100 & $0.0060^{* *}$ & $0.0044^{*}$ & -0.0005 & -0.007 & 0.0012 \\
$\quad$ with Development Index & $(0.002)$ & $(0.003)$ & $(0.002)$ & $(0.005)$ & $(0.002)$ \\
Development Index & $0.0025^{* * *}$ & $0.0483^{* * *}$ & $-0.0458^{* * *}$ & $-0.0013^{*}$ & 0.0004 \\
& $(0.000)$ & $(0.000)$ & $(0.000)$ & $(0.001)$ & $(0.000)$ \\
Panel B: Women & & & & & \\
Refugee Ratio x100 & $-0.0052^{* *}$ & -0.0003 & -0.0028 & 0.0038 & $-0.0047^{* *}$ \\
& $(0.002)$ & $(0.001)$ & $(0.003)$ & $(0.003)$ & $(0.002)$ \\
Interaction of Refugee Ratio x100 & $0.0053^{*}$ & $0.0061^{* * *}$ & -0.0022 & -0.0055 & $0.0058^{*}$ \\
$\quad$ with Development Index & $(0.003)$ & $(0.001)$ & $(0.002)$ & $(0.004)$ & $(0.003)$ \\
Development Index & $-0.0024^{* * *}$ & $0.0230^{* * *}$ & $-0.0236^{* * *}$ & $0.0172^{* * *}$ & $0.0027^{* * *}$ \\
& $(0.001)$ & $(0.000)$ & $(0.000)$ & $(0.001)$ & $(0.001)$ \\
\hline
\end{tabular}

Notes: Each column shows coefficient estimates from regressions that are separately run for women and men. The corresponding standard errors that are clustered at nuts 2 level are provided below the coefficients in parentheses. Each regression is based on 624 observations, consisting of 26 regions, 2 treatment status for each region (either the treated or the synthetic unit), and 12 years (from 2004 to 2015). The regressions control for the year fixed effects and nuts 2 fixed effects in addition to the variables listed in the table. The development index measures the level of development in 2011, and it takes the value of 0.521 for Adana, -0.055 for Gaziantep, -0.273 for Hatay, -1.147 for Sanliurfa, and -1.328 for Mardin (SODE 2013). 
Table 6: Heterogeneity in the Effects of Refugees on Wage Employment and Wages by Regional Development

\begin{tabular}{|c|c|c|c|c|c|c|c|}
\hline & $\begin{array}{l}\text { Non-wage } \\
\text { Workers }\end{array}$ & Wage Worker & Log Wage & $\begin{array}{c}\text { Wage worker, } \\
\text { informal }\end{array}$ & $\begin{array}{c}\text { Log wage, } \\
\text { informal }\end{array}$ & $\begin{array}{l}\text { Wage worker, } \\
\text { formal }\end{array}$ & $\begin{array}{l}\text { Log wage, } \\
\text { formal }\end{array}$ \\
\hline \multicolumn{8}{|l|}{ Panel A: Men } \\
\hline Refugee Ratio x100 & $\begin{array}{l}0.0021 * * \\
(0.0010)\end{array}$ & $\begin{array}{c}-0.0023 * * * \\
(0.0008)\end{array}$ & $\begin{array}{l}-0.0014 \\
(0.0049)\end{array}$ & $\begin{array}{c}-0.0026 * * \\
(0.0012)\end{array}$ & $\begin{array}{c}-0.0105 * * \\
(0.0050)\end{array}$ & $\begin{array}{l}0.0028 * * \\
(0.0014)\end{array}$ & $\begin{array}{c}0.0024 \\
(0.0048)\end{array}$ \\
\hline $\begin{array}{l}\text { Interaction of Refugee Ratio x100 } \\
\text { with Development Index }\end{array}$ & $\begin{array}{l}0.0053^{* *} * \\
(0.0022)\end{array}$ & $\begin{array}{l}-0.0004 \\
(0.0011)\end{array}$ & $\begin{array}{l}0.0134^{*} \\
(0.0078)\end{array}$ & $\begin{array}{c}-0.0039 * * \\
(0.0014)\end{array}$ & $\begin{array}{l}-0.0011 \\
(0.0071)\end{array}$ & $\begin{array}{c}0.0033 \\
(0.0020)\end{array}$ & $\begin{array}{l}0.0210^{* *} \\
(0.0088)\end{array}$ \\
\hline Development Index & $\begin{array}{c}-0.0314 * * * \\
(0.0003)\end{array}$ & $\begin{array}{l}0.0339 * * * \\
(0.0002)\end{array}$ & $\begin{array}{c}0.0158 * * * \\
(0.0013)\end{array}$ & $\begin{array}{c}-0.0060 * * * \\
(0.0003)\end{array}$ & $\begin{array}{c}0.0326^{* * * *} \\
(0.0012)\end{array}$ & $\begin{array}{l}0.0407 * * * \\
(0.0003)\end{array}$ & $\begin{array}{c}-0.0304 * * * \\
(0.0015)\end{array}$ \\
\hline \multicolumn{8}{|l|}{ Panel B: Women } \\
\hline Refugee Ratio x100 & $\begin{array}{l}-0.0034 \\
(0.0021)\end{array}$ & $\begin{array}{l}-0.0009 \\
(0.0010)\end{array}$ & $\begin{array}{l}-0.0039 \\
(0.0108)\end{array}$ & $\begin{array}{c}0.0002 \\
(0.0007)\end{array}$ & $\begin{array}{c}-0.0231 * * * \\
(0.0049)\end{array}$ & $\begin{array}{c}0.0002 \\
(0.0010)\end{array}$ & $\begin{array}{c}0.0008 \\
(0.0062)\end{array}$ \\
\hline $\begin{array}{l}\text { Interaction of Refugee Ratio x } 100 \\
\text { with Development Index }\end{array}$ & $\begin{array}{c}0.0011 \\
(0.0021)\end{array}$ & $\begin{array}{c}0.0036^{* * *} \\
(0.0010)\end{array}$ & $\begin{array}{c}0.0378 * * \\
(0.0174)\end{array}$ & $\begin{array}{c}-0.0029 * * * \\
(0.0007)\end{array}$ & $\begin{array}{l}-0.0052 \\
(0.0060)\end{array}$ & $\begin{array}{c}0.0059 * * * \\
(0.0009)\end{array}$ & $\begin{array}{l}0.0213 * * \\
(0.0088)\end{array}$ \\
\hline Development Index & $\begin{array}{c}-0.0277 * * * \\
(0.0003)\end{array}$ & $\begin{array}{c}0.0271 * * * \\
(0.0001)\end{array}$ & $\begin{array}{l}-0.0275^{* * * *} \\
(0.0028)\end{array}$ & $\begin{array}{c}0.0051 * * * \\
(0.0001)\end{array}$ & $\begin{array}{c}0.0692 * * * \\
(0.0010)\end{array}$ & $\begin{array}{c}0.0213^{* * * *} \\
(0.0002)\end{array}$ & $\begin{array}{c}-0.0516^{* * *} \\
(0.0015)\end{array}$ \\
\hline
\end{tabular}

Notes: Each column shows coefficient estimates from regressions that are separately run for women and men. The corresponding standard errors that are clustered at NUTS-2 level are provided below the coefficients in parentheses. Each regression is based on 624 observations, consisting of 26 regions, 2 treatment status for each region (either the treated or the synthetic unit), and 12 years (from 2004 to 2015). The regressions control for the year fixed effects and NUTS-2 fixed effects in addition to the variables listed in the table. The development index measures the level of development in 2011, and it takes the value of 0.521 for Adana, -0.055 for Gaziantep, -0.273 for Hatay, -1.147 for Sanliurfa, and -1.328 for Mardin (SODE 2013). 
Table 7: Heterogeneity in the Effects of Refugees on Different Sectors by Regional Development

\begin{tabular}{|c|c|c|c|c|c|c|}
\hline & $\begin{array}{c}\text { Agricultural } \\
\text { Workers }\end{array}$ & $\begin{array}{c}\text { Construction } \\
\text { Workers }\end{array}$ & $\begin{array}{c}\text { Manufacturing, } \\
\text { Informal }\end{array}$ & $\begin{array}{c}\text { Manufacturing, } \\
\text { Formal }\end{array}$ & $\begin{array}{l}\text { Service, } \\
\text { Informal }\end{array}$ & $\begin{array}{l}\text { Service, } \\
\text { Formal }\end{array}$ \\
\hline \multicolumn{7}{|l|}{ Panel A: Men } \\
\hline Refugee Ratio x100 & $\begin{array}{l}-0.0013 \\
(0.0009)\end{array}$ & $\begin{array}{c}-0.0019 * * \\
(0.0007)\end{array}$ & $\begin{array}{c}-0.0010 * * \\
(0.0004)\end{array}$ & $\begin{array}{l}0.0018 * * \\
(0.0009)\end{array}$ & $\begin{array}{l}-0.0009 \\
(0.0006)\end{array}$ & $\begin{array}{c}0.0037 * * * \\
(0.0010)\end{array}$ \\
\hline Interaction of Refugee Ratio $\mathrm{x} 100$ & 0.0009 & $-0.0015 * *$ & $-0.0013^{* *}$ & 0.0010 & 0.0002 & $0.0045 * * *$ \\
\hline with Development Index & $(0.0021)$ & $(0.0006)$ & $(0.0006)$ & $(0.0017)$ & $(0.0005)$ & $(0.0012)$ \\
\hline Development Index & $\begin{array}{c}-0.0326 * * * \\
(0.0003) \\
\end{array}$ & $\begin{array}{c}-0.0034^{* * * *} \\
(0.0001) \\
\end{array}$ & $\begin{array}{c}0.0042 * * * \\
(0.0001)\end{array}$ & $\begin{array}{c}0.0261 * * * \\
(0.0003)\end{array}$ & $\begin{array}{c}-0.0089 * * * \\
(0.0001) \\
\end{array}$ & $\begin{array}{c}0.0197 * * * \\
(0.0002)\end{array}$ \\
\hline \multicolumn{7}{|l|}{ Panel B: Women } \\
\hline Refugee Ratio x100 & $\begin{array}{l}-0.0027 \\
(0.0023)\end{array}$ & $\mathrm{x}$ & $\begin{array}{l}-0.0002 \\
(0.0003)\end{array}$ & $\begin{array}{l}-0.0001 \\
(0.0003)\end{array}$ & $\begin{array}{c}0.0001 \\
(0.0005)\end{array}$ & $\begin{array}{c}0.0003 \\
(0.0009)\end{array}$ \\
\hline Interaction of Refugee Ratio x100 & -0.0009 & $\mathrm{x}$ & -0.0002 & $0.0011 * * *$ & $-0.0012^{* *}$ & $0.0047 * * *$ \\
\hline with Development Index & $(0.0020)$ & & $(0.0002)$ & $(0.0002)$ & $(0.0005)$ & $(0.0008)$ \\
\hline Development Index & $\begin{array}{c}-0.0301 * * * \\
(0.0003)\end{array}$ & $\mathrm{x}$ & $\begin{array}{c}0.0026^{* * *} \\
0.0000\end{array}$ & $\begin{array}{c}0.0070 * * * \\
0.0000\end{array}$ & $\begin{array}{c}0.0033 * * * \\
(0.0001)\end{array}$ & $\begin{array}{c}0.0145 * * * \\
(0.0001)\end{array}$ \\
\hline
\end{tabular}

Notes: Each column shows coefficient estimates from regressions that are separately run for women and men. The corresponding standard errors that are clustered at NUTS-2 level are provided below the coefficients in parentheses. The dependent variables are the employment of the specified group of workers. Each regression uses 624 observations. See notes to Table 6 for further details of the regressions. The results of construction workers for women are excluded from the table because there are few women working in the construction sector in the data. 
Figure 1: Employment, Formal Employment, Informal Employment, Unemployment, and Labor Force Participation of Men in Each of the Five Focus Regions and Its Synthetic Control

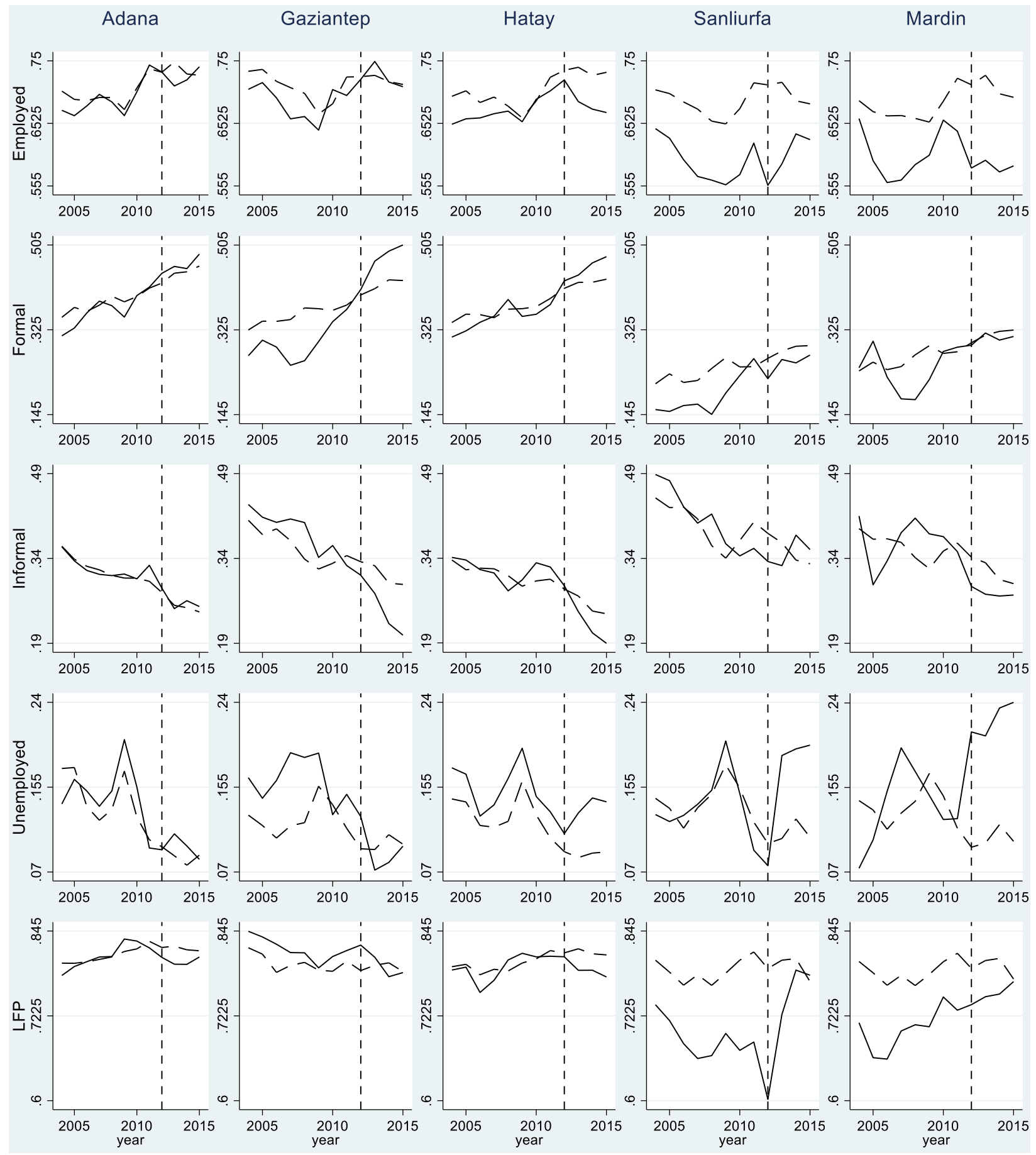

Notes: The data come from the 2004-15 Household Labor Force Surveys of Turkey. The sample is restricted to 18- to 64-year-old individuals. The solid lines track the outcomes for the five focus regions and the dashed lines represent the values for the synthetic controls. The synthetic units are constructed by matching over the age and educational distribution of the population, the sectoral distribution of workers (agriculture, manufacturing, construction, and service), the employment types of workers (employed, wage worker, self-employed, and employer), the proportion of public workers, and the value of the dependent variable in years 2006, 2009, and 2011. 
Figure 2: Employment, Formal Employment, Informal Employment, Unemployment, and Labor Force Participation of Women in Each of the Five Focus Regions and Its Synthetic Control

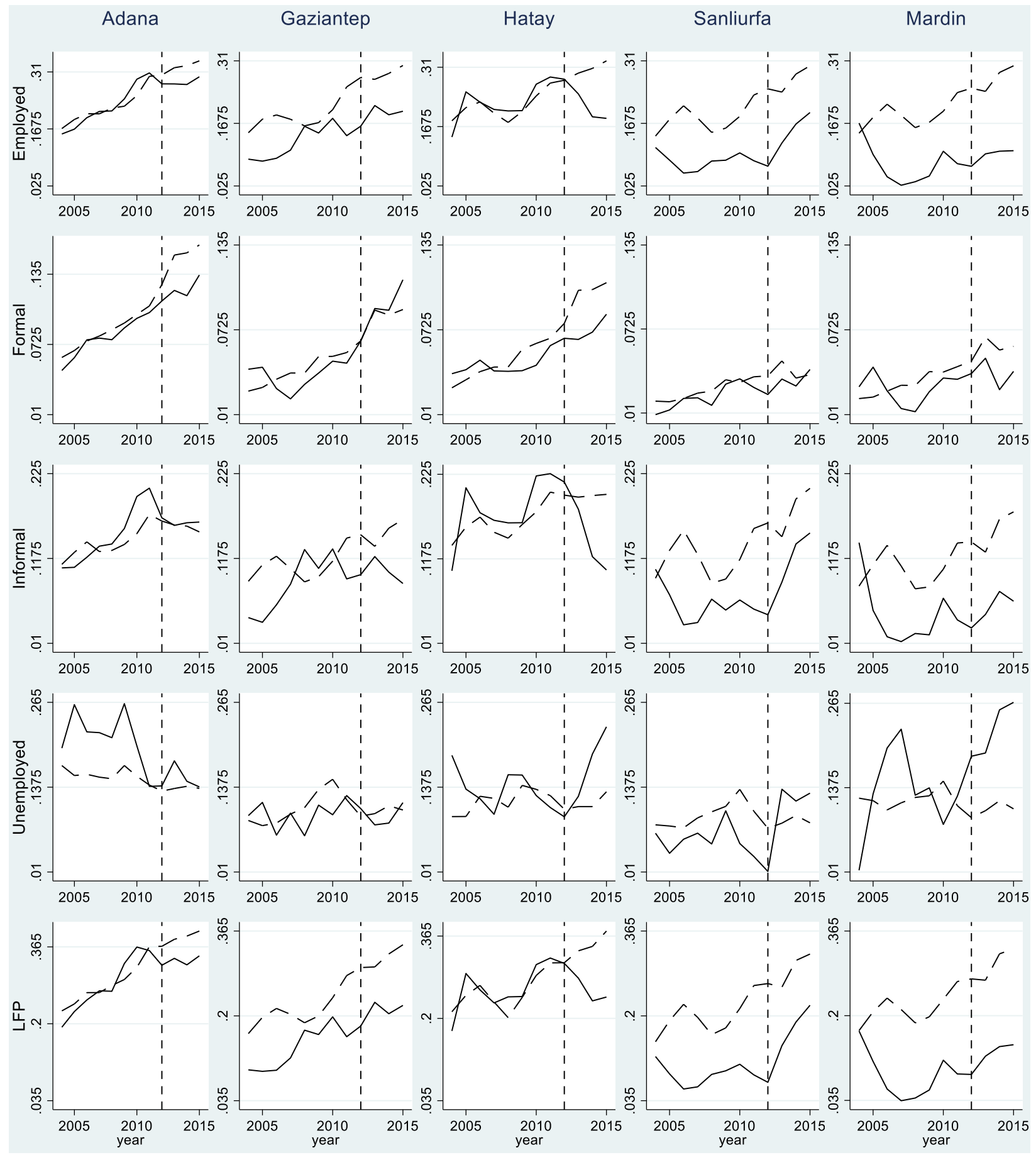

Notes: The data come from the 2004-15 Household Labor Force Surveys of Turkey. The sample is restricted to 18- to 64-year-old individuals. The solid lines track the outcomes for the five focus regions and the dashed lines represent the values for the synthetic controls. The synthetic units are constructed by matching over the age and educational distribution of the population, the sectoral distribution of workers (agriculture, manufacturing, construction, and service), the employment types of workers (employed, wage worker, self-employed, and employer), the proportion of public workers, and the value of the dependent variable in years 2006, 2009, and 2011. 
Figure 3: Refugee Impact by Development Level for Main Outcomes
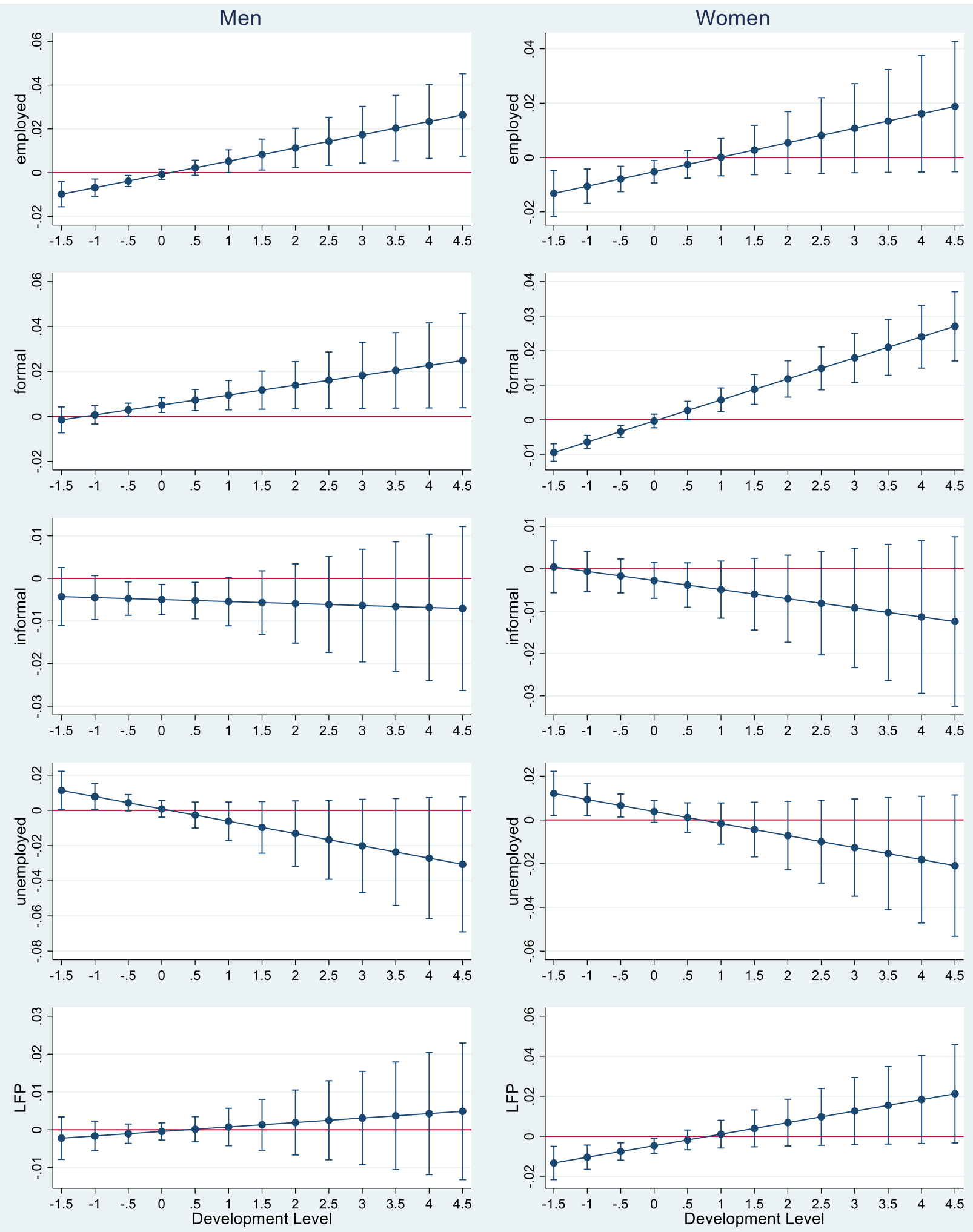

Notes: The estimates show the joint effects of refugee ratio and its interaction with development level at various values of the development level, based on the estimates in Table 5. The vertical bars show the $90 \%$ confidence intervals. 
Figure 4: Firm Establishment in the Five Focus Regions
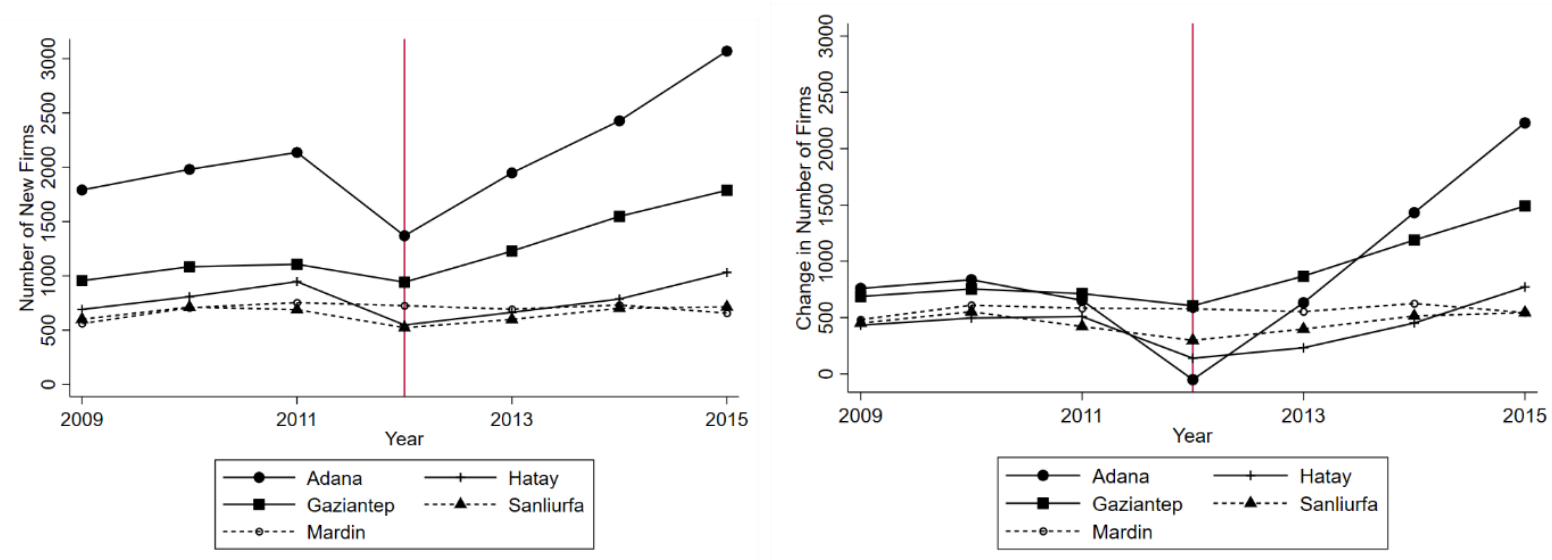

Notes: The data come from Union of Chambers and Commodity Exchanges of Turkey. 


\section{Appendix Tables and Figures}

Table A1: The List of Measures Employed in the Construction of the Development Index

Demographical Measures: 1) Population density, 2) age-specific fertility rate (ages 15-49), 3) the share of young dependent population (ages 0-14), 4) net migration rate, 5) urbanization rate.

Employment Measures: 1) Unemployment rate, 2) labor force participation rate, 3) the share of working age population (ages 15-64), 4) the share of manufacturing among formal employment, 5) the share of formal employment among all population, 6) the average daily earnings, 7) the average daily earnings of women, 8) the employment rate.

Education Measures: 1) Literacy rate, 2) literacy rate of women, 3) enrollment rate in secondary education, 4) enrollment rate in vocational high schools, 5) the average score of residents in the university entrance exam, 6) the share of college educated population among those older than 22 .

Health Measures: 1) The number of hospital beds per 100 thousand people, 2) the number of physicians per 10 thousand people, 3) the number of dentists per 10 thousand people, 4) the number of pharmacies per 10 thousand people, 5) the share of people who are eligible for free health care.

Competitiveness and Innovation Measures: 1) The region's share in total exports of Turkey, 2) the value of exports per capita, 3) the region's share in the total population of manufacturing firms in Turkey, 4) the number of registered manufacturing firms, 5) the amount of electricity consumption by manufacturing firms per capita, 6) the region's share of the total area occupied by organized industrial zones in Turkey, 7) the region's share of the total number of firms in small industrial zones in Turkey, 8) the share of the total capital of new firms established in the region within Turkey, 9) the number of new firms with foreign capital per 10 thousand people, 10) the number of trademark applications per 100 thousand people, 11) the number of patent applications per 100 thousand people, 12) the share of the population with master and doctoral degrees among those older than 30,13 ) the value of agricultural production per capita in rural areas, 14) the region's share of the total number of hotel beds in Turkey, 15) The region's share of the total amount of investments with incentive certificates in Turkey

Financial measures: 1) The region's share of total bank credits in Turkey, 2) the region's share of total bank deposits in Turkey, 3) the amount of bank deposits per capita, 4) the number of active users of internet banking per thousand people, 5) the number of corporate users of internet banking per thousand people, 6) the amount of budget revenues per capita, 7) the region's share of the total amount of taxes collected in Turkey.

Accessibility measures: 1) The share of asphalt and concrete roads in rural areas, 2) the distance to the closest airport, 3) the number of broadband (internet) users per household, 4) the number of subscribers of GSM operators per capita, 5) the amount of freight per $\mathrm{km}$ transported in the region's highways, 6) the ratio of the length of railroads in the region to total area.

Life quality: 1) The area of shopping malls per thousand people, 2) the share of population with sewage services provided by local municipalities, 3) the amount of electricity consumption by households per capita, 4) the number of private cars per 10 thousand people, 5) the average emission of sulfur dioxide, 6) the average emission of particulates, 7) the share of population without social security coverage, 8) the number of convictions per 100 thousand people, 9) the number of suicides per 100 thousand people.

Source: Table 1 of the report by Turkish Ministry of Development (2013). 
Table A2: Weights for Units in the Synthetic Control

\begin{tabular}{|c|c|c|c|}
\hline \multicolumn{2}{|l|}{ A) Men } & \multicolumn{2}{|l|}{ B) Women } \\
\hline \multicolumn{2}{|l|}{ Employment } & \multicolumn{2}{|l|}{ Employment } \\
\hline Adana & $\begin{array}{l}\text { Istanbul (0.223), Izmir (0.123), Aydin (0.148), Antalya (0.062), } \\
\text { Malatya (0.425), Van (0.021) }\end{array}$ & Adana & $\begin{array}{l}\text { Istanbul (0.09), Izmir (0.154), Kocaeli (0.585), Ankara (0.009), } \\
\text { Antalya (0.011), Van (0.151) }\end{array}$ \\
\hline Gaziantep & Istanbul (0.083), Bursa (0.468), Van (0.449) & Gaziantep & Istanbul (0.354), Kayseri (0.248), Van (0.399) \\
\hline Hatay & Istanbul (0.228), Kayseri (0.535), Malatya (0.129), Van (0.108) & Hatay & Kocaeli $(0.352)$, Konya (0.012), Kirikkale $(0.385)$, Van $(0.251)$ \\
\hline Sanliurfa & Ankara (0.089), Malatya (0.15), Van (0.762) & Sanliurfa & Istanbul (0.181), Ankara (0.05), Van (0.769) \\
\hline Mardin & Malatya (0.528), Van (0.433) & Mardin & Ankara (0.331), Van (0.669) \\
\hline \multicolumn{2}{|c|}{ Formal Employment } & \multicolumn{2}{|c|}{ Formal Employment } \\
\hline Adana & $\begin{array}{l}\text { Istanbul (0.106), Izmir (0.379), Ankara (0.002), Trabzon (0.173), } \\
\text { Van }(0.340)\end{array}$ & $\begin{array}{l}\text { Adana } \\
\text { Gaziantep }\end{array}$ & $\begin{array}{l}\text { Istanbul }(0.301), \text { Kirikkale }(0.122), \text { Kayseri }(0.578) \\
\text { Konya }(0.111), \text { Kayseri }(0.533) \text {, Van }(0.356)\end{array}$ \\
\hline Gaziantep & Bursa (0.438), Van (0.562) & Hatay & Kirikkale (0.165), Kayseri (0.645), Malatya (0.045), Van (0.146) \\
\hline Hatay & Istanbul (0.221), Bursa (0.015), Zonguldak (0.340), Van (0.424) & Sanliurfa & Ankara (0.006), Kayseri (0.071), Van (0.923) \\
\hline Sanliurfa & Istanbul (0.008), Ankara (0.053), Van (0.939) & Mardin & Kayseri (0.333), Van (0.667) \\
\hline \multirow[t]{2}{*}{ Mardin } & Istanbul (0.038), Ankara (0.112), Van (0.850) & & \\
\hline & & \multicolumn{2}{|c|}{ Informal Employment } \\
\hline \multicolumn{2}{|c|}{ Informal Employment } & Adana & Istanbul (0.073), Kocaeli (0.56), Ankara (0.101), Antalya (0.099), \\
\hline \multirow[t]{3}{*}{ Adana } & Istanbul (0.248), Izmir (0.023), Ankara (0.011), Konya (0.127), & & Trabzon $(0.044)$, Van $(0.123)$ \\
\hline & Antalya (0.038), Kastamonu (0.008), Trabzon (0.306), Malatya & Gaziantep & Istanbul (0.399), Konya (0.09), Kayseri (0.086), Van (0.425) \\
\hline & $(0.039), \operatorname{Van}(0.2)$ & Hatay & Kocaeli (0.363), Konya (0.093), Kirikkale (0.162), Zonguldak \\
\hline Gaziantep & Istanbul (0.133), Manisa (0.358), Agri (0.088), Van (0.421) & & (0.079), Trabzon (0.025), Van (0.278) \\
\hline \multirow[t]{2}{*}{ Hatay } & Istanbul (0.129), Aydin (0.17), Manisa (0.086), Konya (0.323), & Sanliurfa & Istanbul (0.212), Ankara (0.068), Van (0.72) \\
\hline & Zonguldak (0.034), Van (0.257) & Mardin & Ankara (0.427), Van $(0.573)$ \\
\hline Sanliurfa & Istanbul (0.181), Ankara (0.042), Antalya (0.025), Van (0.752) & & \\
\hline \multirow[t]{2}{*}{ Mardin } & Ankara (0.136), Konya (0.229), Malatya (0.135), Van (0.5) & Unemployment & \\
\hline & & Adana & Izmir (0.049), Kocaeli (0.491), Ankara (0.198), Malatya (0.262) \\
\hline \multicolumn{2}{|l|}{ Unemployment } & Gaziantep & Istanbul (0.465), Kocaeli (0.006), Ankara (0.003), Zonguldak \\
\hline Adana & Istanbul (0.127), Izmir (0.136), Malatya (0.736) & & $(0.071), \operatorname{Van}(0.455)$ \\
\hline Gaziantep & Kocaeli (0.604), Malatya (0.058), Van (0.337) & Hatay & Kocaeli (0.508), Kirikkale (0.402), Van (0.09) \\
\hline Hatay & $\begin{array}{l}\text { Istanbul (0.102), Kocaeli (0.361), Kirikkale (0.09), Malatya } \\
(0.318) \text {, Van (0.128) }\end{array}$ & Sanliurfa & $\begin{array}{l}\text { Istanbul (0.168), Ankara (0.167), Kirikkale (0.024), Agri (0.087), } \\
\text { Van (0.554) }\end{array}$ \\
\hline Sanliurfa & Istanbul (0.039), Malatya (0.373), Van (0.588) & Mardin & Istnabul (0.117), Ankara (0.391), Van (0.491) \\
\hline \multirow[t]{2}{*}{ Mardin } & Ankara (0.166), Malatya (0.328), Van (0.506) & & \\
\hline & & \multicolumn{2}{|c|}{ Labor Force Participation } \\
\hline \multicolumn{2}{|c|}{ Labor Force Participation } & Adana & Istanbul (0.176), Izmir (0.06), Kocaeli (0.473), Ankara (0.011), \\
\hline \multirow[t]{2}{*}{ Adana } & Istanbul (0.019), Izmir (0.105), Kocaeli (0.275), Ankara (0.072), & & Antalya (0.126), Trabzon (0.038), Van (0.115) \\
\hline & Antalya (0.284), Trabzon (0.002), Malatya (0.093), Van (0.151) & Gaziantep & Istanbul (0.405), Kayseri (0.152), Van (0.443) \\
\hline Gaziantep & Bursa (0.584), Van (0.416) & Hatay & Kocaeli (0.326), Kirikkale (0.485), Trabzon (0.012), Van (0.177) \\
\hline \multirow[t]{2}{*}{ Hatay } & Istanbul (0.165), Aydin (0.22), Kocaeli (0.175), Konya (0.049), & Sanliurfa & Istanbul (0.105), Ankara (0.108), Van (0.787) \\
\hline & Kayseri $(0.201)$, Van $(0.19)$ & Mardin & Ankara (0.374), Van (0.626) \\
\hline Sanliurfa & Ankara (0.168), Van (0.832) & & \\
\hline Mardin & Ankara (0.226), Van (0.774) & & \\
\hline
\end{tabular}


Table A3: Average Effect of Refugees on Main Labor Market Outcomes for 2013 - 2015

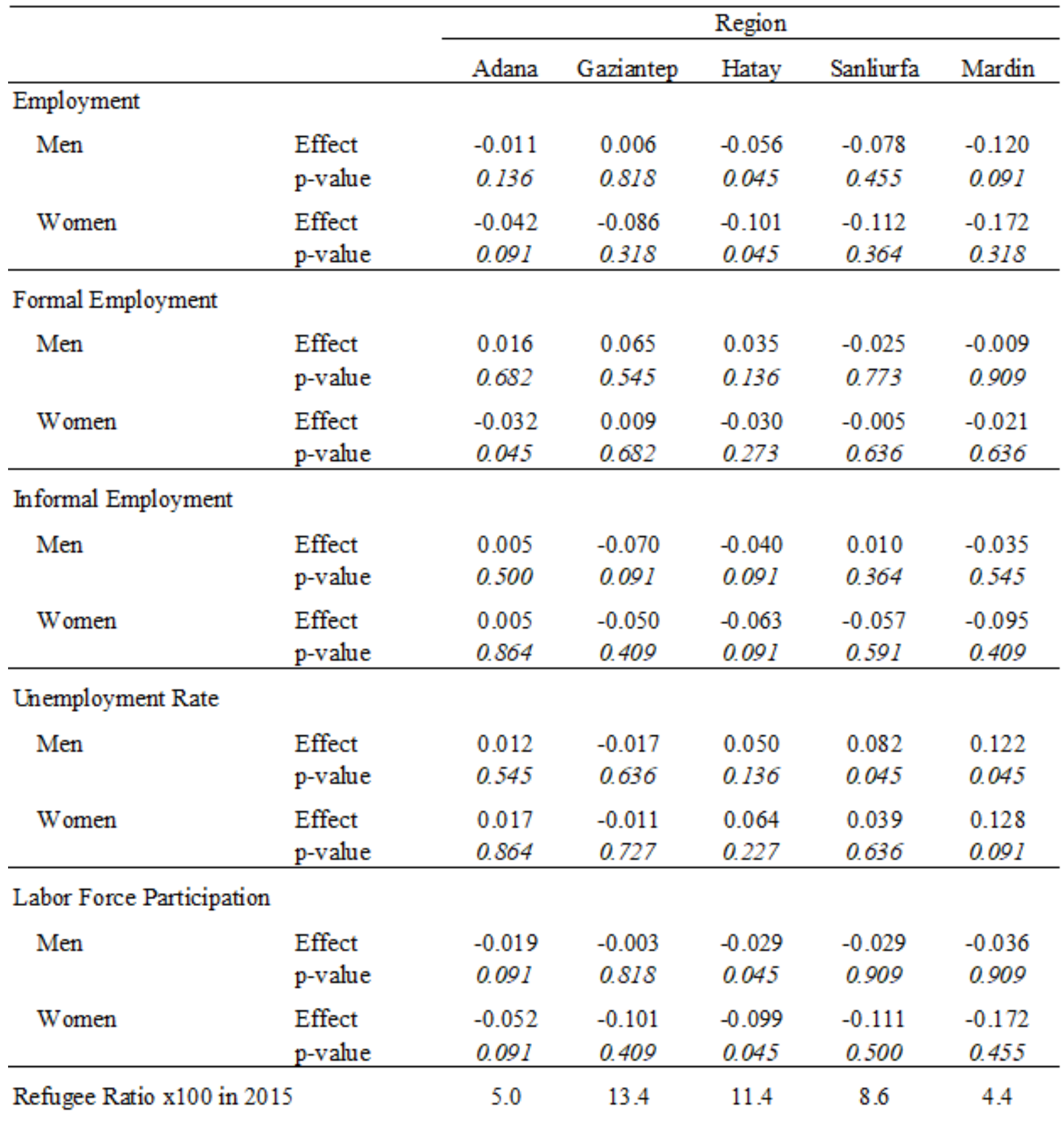

Notes: The table shows the average difference between the labor market outcome of the treated and the synthetic unit in the 2013-2015 period separately for men and women in each region. The corresponding p-values are provided below the magnitudes in italics. The synthetic units are constructed by matching over the age distribution of population (ages 18-24,2549, and 50-65), the educational distibution of population (illiterate and no degree, primary and secondarydegree, high school degree, college degree), the sectoral distribution of workers (agriculture, manufacturing, construction, and service), the employment types of workers (employed, wage worker, self-employed, and employer), the proportion of public workers, and the value of the dependent variable in years 2006, 2009, and 2011. 
Table A4: Alternative Sets of Predictor Variables in the Selection of Synthetic Control Group

\begin{tabular}{|c|c|c|c|c|c|}
\hline \multicolumn{6}{|c|}{ Panel A: Using the value of the outcome variable in each year before treatment but no other predictors } \\
\hline & Employed & Formal & Informal & Unemployment & LFP \\
\hline \multicolumn{6}{|l|}{ For Men } \\
\hline Refugee Ratio x100 & $\begin{array}{c}-0.0002 \\
(0.002)\end{array}$ & $\begin{array}{c}0.0067 * * \\
(0.003)\end{array}$ & $\begin{array}{c}-0.0053^{* *} \\
(0.002)\end{array}$ & $\begin{array}{c}-0.000009 \\
(0.002)\end{array}$ & $\begin{array}{l}-0.0016 \\
(0.002)\end{array}$ \\
\hline $\begin{array}{l}\text { Interaction of Refugee Ratio x100 } \\
\text { with Development Index }\end{array}$ & $\begin{array}{c}0.0055^{* *} \\
(0.002)\end{array}$ & $\begin{array}{l}0.0046^{*} \\
(0.003)\end{array}$ & $\begin{array}{l}-0.0002 \\
(0.003)\end{array}$ & $\begin{array}{l}-0.0066 \\
(0.004)\end{array}$ & $\begin{array}{l}-0.0008 \\
(0.003)\end{array}$ \\
\hline \multicolumn{6}{|l|}{ For Women } \\
\hline Refugee Ratio x100 & $\begin{array}{c}-0.0048 * \\
(0.003)\end{array}$ & $\begin{array}{l}0.0011 \\
(0.001)\end{array}$ & $\begin{array}{l}0.0003 \\
(0.003)\end{array}$ & $\begin{array}{c}0.001 \\
(0.001)\end{array}$ & $\begin{array}{l}-0.0035 \\
(0.003)\end{array}$ \\
\hline $\begin{array}{l}\text { Interaction of Refugee Ratio x100 } \\
\text { with Development Index }\end{array}$ & $\begin{array}{l}0.0056^{*} \\
(0.003)\end{array}$ & $\begin{array}{c}0.0068 * * * \\
(0.001)\end{array}$ & $\begin{array}{l}-0.0022 \\
(0.003) \\
\end{array}$ & $\begin{array}{c}-0.00005 \\
(0.001) \\
\end{array}$ & $\begin{array}{r}0.0056^{*} \\
(0.003) \\
\end{array}$ \\
\hline
\end{tabular}

Panel B: Using values of the outcome variable in odd years before treatment and predictors from the baseline

\begin{tabular}{lccccc} 
& Employed & Formal & Informal & Unemployment & LFP \\
\cline { 2 - 6 } For Men & & & & & \\
$\quad$ Refugee Ratio x100 & -0.0008 & $0.0069^{* * *}$ & $-0.0055^{* * *}$ & 0.0004 & 0.00002 \\
& $(0.001)$ & $(0.002)$ & $(0.002)$ & $(0.002)$ & $(0.001)$ \\
& $0.0057^{* *}$ & $0.0045^{*}$ & -0.0003 & -0.0055 & 0.0016 \\
$\quad$ Interaction of Refugee Ratio x100 & $(0.002)$ & $(0.003)$ & $(0.002)$ & $(0.004)$ & $(0.002)$ \\
$\quad$ with Development Index & & & & & \\
For Women & $-0.0052^{*}$ & 0.00002 & -0.0024 & 0.0005 & $-0.0047^{*}$ \\
$\quad$ Refugee Ratio x100 & $(0.003)$ & $(0.001)$ & $(0.003)$ & $(0.001)$ & $(0.003)$ \\
& $0.0054^{*}$ & $0.0062^{* * *}$ & -0.0018 & 0.0007 & $0.0054^{*}$ \\
$\quad$ Interaction of Refugee Ratio x100 & $(0.003)$ & $(0.001)$ & $(0.002)$ & $(0.001)$ & $(0.003)$ \\
$\quad$ with Development Index & & & & &
\end{tabular}

Panel C: Using values of the outcome variable in even years before treatment and predictors from the baseline

For Men

Refugee Ratio x100

Interaction of Refugee Ratio x100 with Development Index

For Women

Refugee Ratio x100

Interaction of Refugee Ratio x100 with Development Index

\begin{tabular}{ccccc} 
Employed & Formal & Informal & Unemployment & LFP \\
\hline & & & & \\
-0.0008 & $0.0066^{* *}$ & $-0.0054^{* *}$ & 0.0005 & -0.0006 \\
$(0.001)$ & $(0.003)$ & $(0.002)$ & $(0.002)$ & $(0.002)$ \\
$0.0061^{* *}$ & 0.0043 & -0.00003 & -0.0055 & 0.0012 \\
$(0.002)$ & $(0.003)$ & $(0.002)$ & $(0.004)$ & $(0.002)$ \\
& & & & \\
$-0.0055^{*}$ & -0.0005 & -0.003 & 0.0003 & $-0.0053^{* *}$ \\
$(0.003)$ & $(0.001)$ & $(0.003)$ & $(0.001)$ & $(0.003)$ \\
$0.0050^{*}$ & $0.0061^{* * *}$ & -0.0019 & 0.0006 & $0.0052^{*}$ \\
$(0.003)$ & $(0.001)$ & $(0.002)$ & $(0.001)$ & $(0.003)$
\end{tabular}

Notes: Each column in each panel shows coeffiecient estimates from a separate regression that controls for the year fixed effects and nuts2 fixed effects. The standard errors that are clustered at nuts 2 level are presented in parnetheses. Values of the dependent variable for synthetic regions come from the SCM estimates with different specifications as desribed in the title of each panel. Predictors from the bassline specification include the age distribution and the educational distibution of population, the sectoral distribution and the employment types of workers, and the proportion of public workers. 
Table A5: Robustness to the Exclusion of Regions with Outlier Values of Development Index

\begin{tabular}{lccccc}
\hline Panel A) All regions excluding Istanbul & & & & \\
& Employed & Formal & Informal & Unemploymer & LFP \\
\cline { 2 - 6 } For Men & & & & & \\
$\quad$ Refugee Ratio x100 & 0.0002 & $0.0062^{* * *}$ & $-0.0053^{* *}$ & -0.0012 & -0.0011 \\
& $(0.001)$ & $(0.002)$ & $(0.002)$ & $(0.002)$ & $(0.001)$ \\
Interaction of Refugee Ratio x100 & $0.0088^{* * *}$ & $0.0075^{* * *}$ & -0.0013 & $-0.0125^{* * *}$ & -0.0005 \\
$\quad$ with Development Index & $(0.003)$ & $(0.002)$ & $(0.004)$ & $(0.004)$ & $(0.003)$ \\
& & & & & \\
For Women & & & & & \\
$\quad$ Refugee Ratio x100 & $-0.0050^{* *}$ & 0.0000 & -0.0028 & 0.0024 & $-0.0046^{*}$ \\
& $(0.002)$ & $(0.001)$ & $(0.003)$ & $(0.003)$ & $(0.002)$ \\
$\quad$ Interaction of Refugee Ratio x100 & 0.0059 & $0.0070^{* * *}$ & -0.0026 & $-0.0094^{*}$ & 0.0059 \\
$\quad$ with Development Index & $(0.005)$ & $(0.002)$ & $(0.003)$ & $(0.005)$ & $(0.005)$ \\
\hline
\end{tabular}

Panel B) All regions exlcuding Istanbul, Ankara, Izmir

\section{For Men}

Refugee Ratio x100

Interaction of Refugee Ratio x100 with Development Index

\begin{tabular}{ccccc} 
Employed & Formal & Informal & Unemploymer & LFP \\
\hline & & & & \\
0.0005 & $0.0068 * * *$ & $-0.0060 * * *$ & $-0.0022^{*}$ & $-0.0018 * *$ \\
$(0.001)$ & $(0.001)$ & $(0.002)$ & $(0.001)$ & $(0.001)$ \\
$0.0094 * *$ & $0.0092 * * *$ & -0.0036 & $-0.0157 * * *$ & $-0.0030 *$ \\
$(0.003)$ & $(0.002)$ & $(0.004)$ & $(0.004)$ & $(0.002)$
\end{tabular}

For Women

\begin{tabular}{cccccc} 
Refugee Ratio x100 & $-0.0049 *$ & 0.0002 & -0.0032 & 0.0011 & $-0.0053^{* *}$ \\
& $(0.002)$ & $(0.001)$ & $(0.003)$ & $(0.002)$ & $(0.002)$ \\
Interaction of Refugee Ratio x100 & 0.0058 & $0.0074 * * *$ & -0.0038 & $-0.0133^{* *}$ & 0.0036 \\
with Development Index & $(0.005)$ & $(0.002)$ & $(0.004)$ & $(0.006)$ & $(0.005)$ \\
\hline
\end{tabular}

Notes: Each column in each panel shows coeffiecient estimates from a separate regression that controls for the year fixed effects and nuts 2 fixed effects. The standard errors that are clustered at nuts 2 level are presented in parnetheses. Values of the dependent variable for synthetic regions come from the SCM estimates with different specifications as desribed in the title of each panel. Predictors from the baseline specification include the age distribution and the educational distibution of population, the sectoral distribution and the employment types of workers, and the proportion of public workers. 
Figure A1: Refugee Impact by Development Level for Wage Employment and Wages
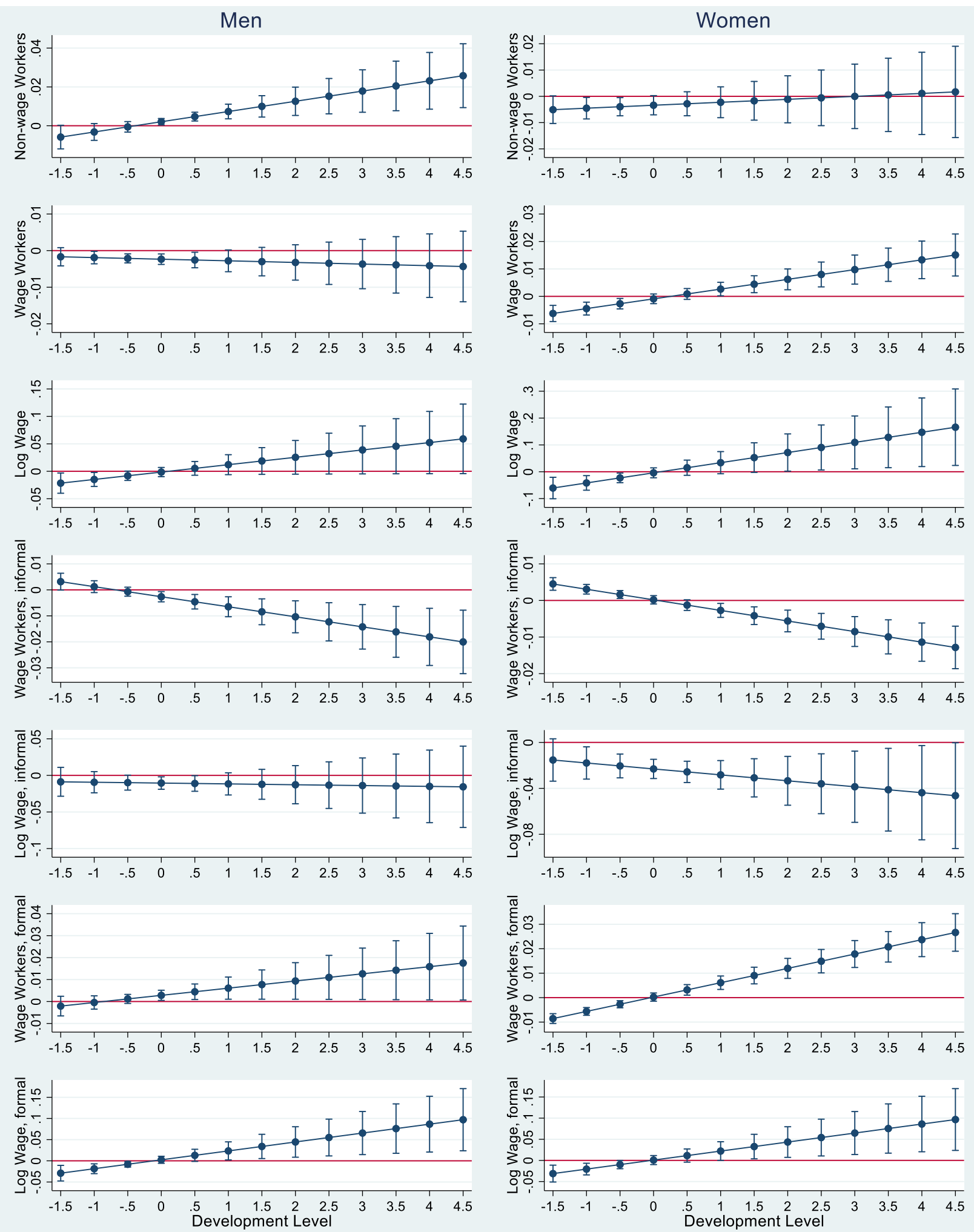

Notes: The estimates show the joint effects of refugee ratio and its interaction with development level at various values of the development level, based on the estimates in Table 6 . The vertical bars show the $90 \%$ confidence intervals. 
Figure A2: Refugee Impact by Development Level for Different Sectors
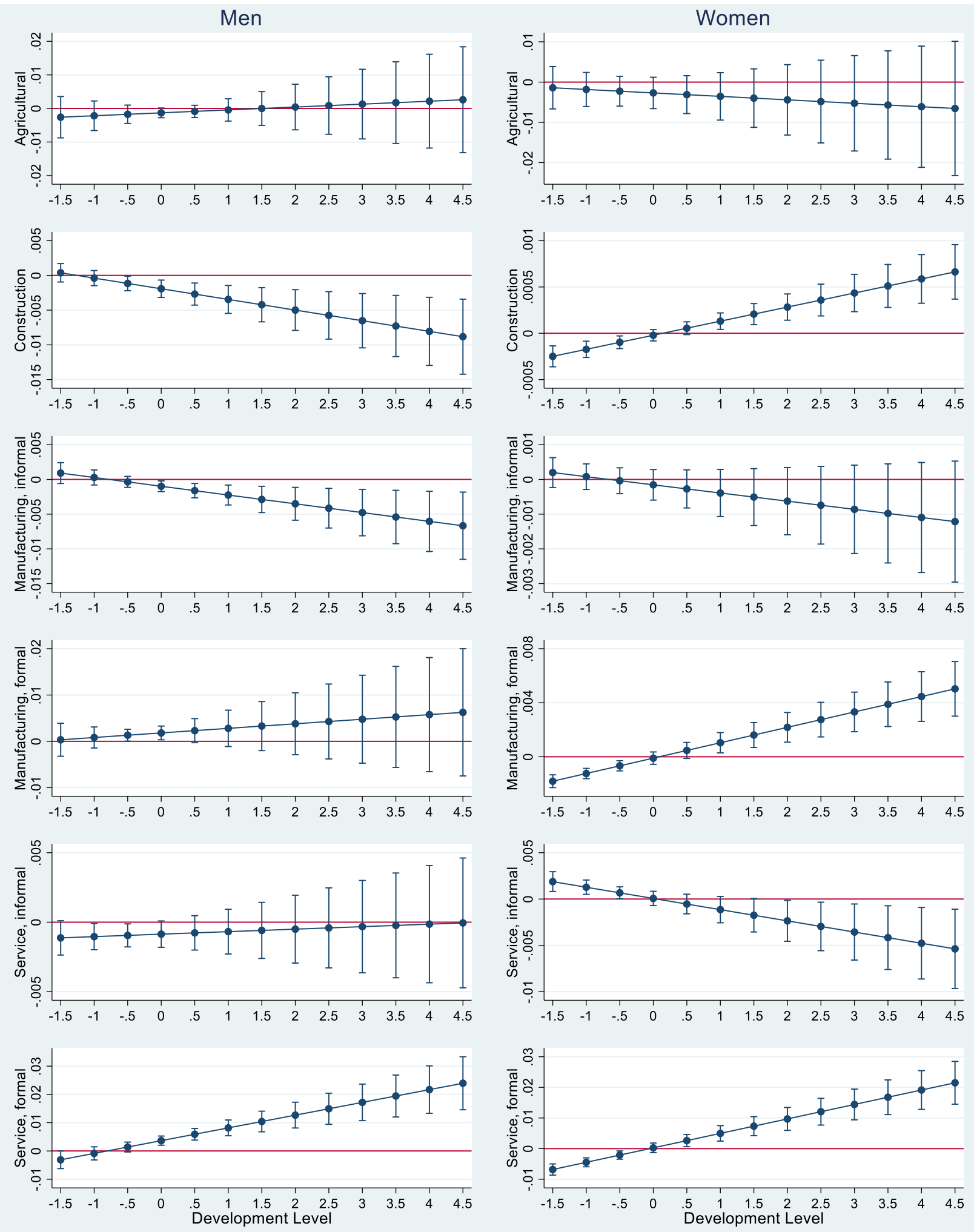

Notes: The estimates show the joint effects of refugee ratio and its interaction with development level at various values of the development level, based on the estimates in Table 7 . The vertical bars show the $90 \%$ confidence intervals. 
Figure A3: Refugee Impact by Development Level for Main Outcomes, Istanbul Region excluded
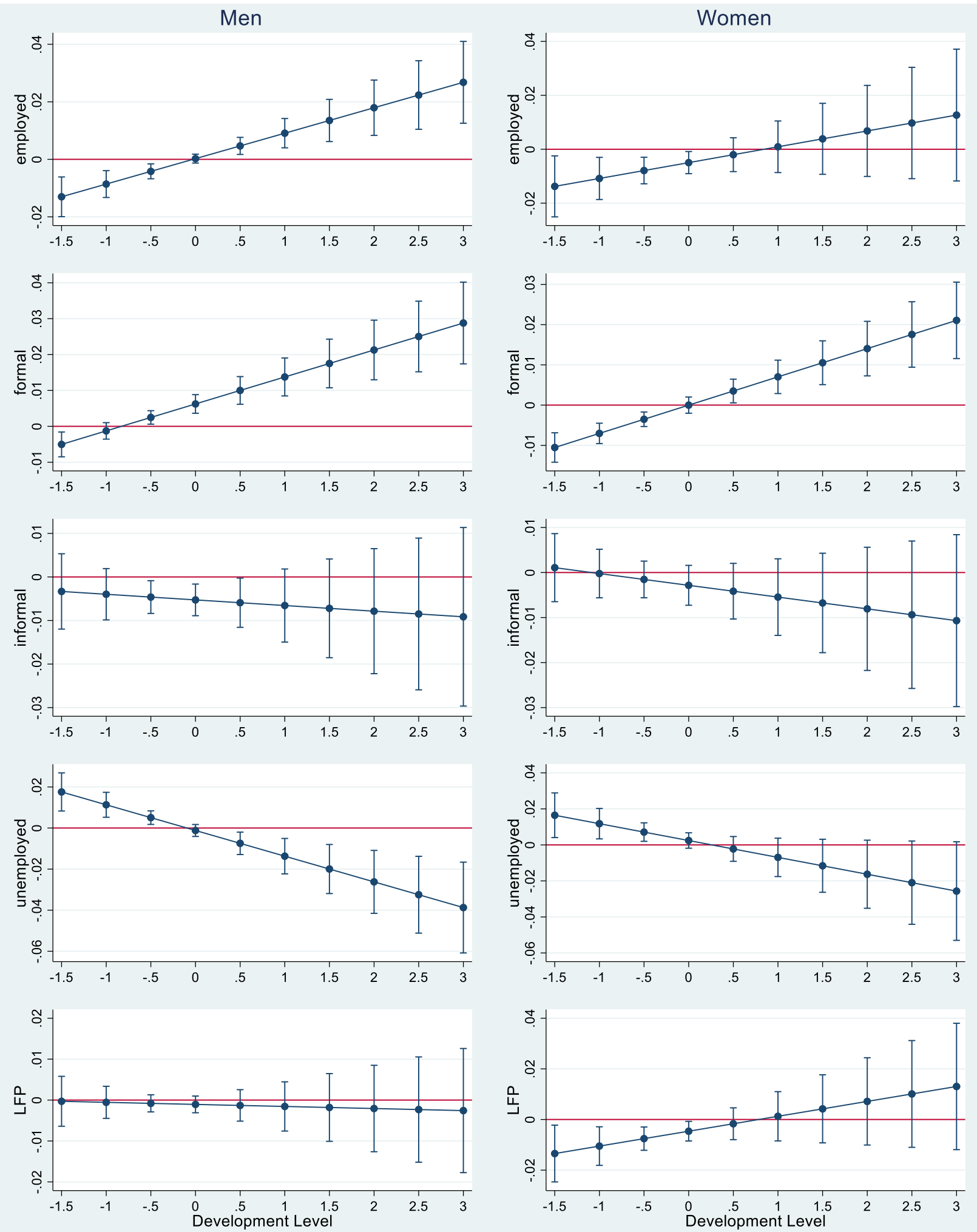

Notes: The estimates show the joint effects of refugee ratio and its interaction with development level at various values of the development level, based on the estimates in Table A5. The vertical bars show the $90 \%$ confidence intervals. 
Figure A4: Refugee Impact by Development Level for Main Outcomes - Istanbul, Ankara, and Izmir regions excluded (development level is restricted to the $(-1.5,1.5)$ range)
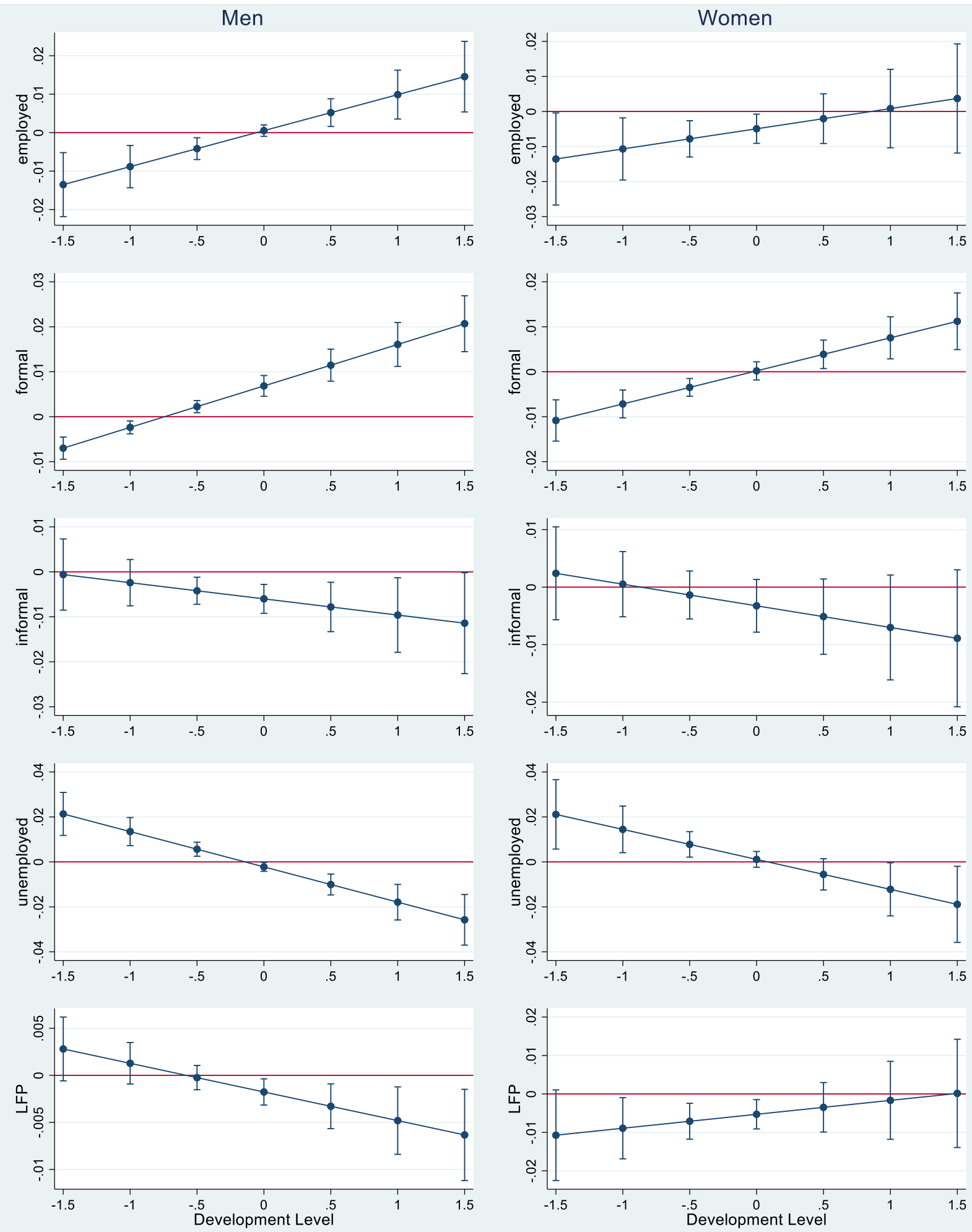

Notes: The estimates show the joint effects of refugee ratio and its interaction with development level at various values of the development level, based on the estimates in Table A5. The vertical bars show the 90\% confidence intervals. 